$$
\text { ilmiyat }
$$

Tokat IImiyat Dergisi | Tokat Journal of IImiyat

9/1 (Haziran | June 2021)

ISSN 2717-6134 | e-ISSN 2717-610X

\title{
Geleneksel Trabzon Cami Mimarisinin Son Temsilcilerinden İki Örnek; Arsin Güneyce Mahallesi Orta Camii ve Elmaalan Mahallesi Merkez Camii
}

Two Examples of the Last Representatives of Traditional Trabzon Mosque Architecture; Arsin Güneyce Mahallesi Orta Mosque ve Elmaalan Mahallesi Merkez Mosque

\section{Yavuz SARI}

Öğr. Gör., Tokat Gaziosmanpaşa Üniversitesi Lecturer, Tokat Gaziosmanpaşa University İslami İlimler Fakültesi Faculty of Islamic Sciences Türk İslam Edebiyatı Ana Bilim Dalı Department of Turkish Islamic Literature Tokat | Türkiye Tokat|Turkey yavuz.sari@gop.edu.tr orcid.org/0000-0001-6847-2600

\section{Makale Bilgisi | Article Information}

Makale Türü | Araştırma Makalesi Article Types | Research Article Geliş Tarihi | 02 Nisan 2021 Received | 02 April 2021 Kabul Tarihi | 15 Haziran 2021 Accepted | 15 June 2021 Yayın Tarihi | 30 Haziran 2021 Published | 30 June 2021

\section{Atıf | Cite as:}

Sarı, Yavuz. "Geleneksel Trabzon Cami Mimarisinin Son Temsilcilerinden İki Örnek; Arsin Güneyce Mahallesi Orta Camii ve Elmaalan Mahallesi Merkez Camii [Two Examples of the Last Representatives of Traditional Trabzon Mosque Architecture; Arsin Güneyce Mahallesi Orta Mosque ve Elmaalan Mahallesi Merkez Mosque]". Tokat IImiyat Dergisi | Tokat Journal of Ilmiyat 9/1 (Haziran | June 2021), 375-406. https://doi.org/10.51450/ilmiyat.908754

\section{Intihal | Plagiarism:}

Bu makale, iTenticate aracılı̆̆ıyla taranmış ve intihal içermediği teyit edilmiştir. | This article, has been scanned by iThenticate and no plagiarism has been detected.

\section{Copyright $\odot$}

Published by Tokat Gaziosmanpaşa University Faculty of Islamic Sciences. Tokat | Turkey. https://dergipark.org.tr/ilmiyat 
Two Examples of the Last Representatives of Traditional Trabzon Mosque Architecture; Arsin Güneyce Mahallesi Orta Mosque ve Elmaalan Mahallesi Merkez Mosque

Abstract: The subject of the study is Güneyce Mahallesi Orta Mosque and Elmaalan Mahallesi Merkez Mosque, which are located in the Arsin district of Trabzon and were built in the 1960s. With the conquest of Trabzon in 1461 by Fatih Sultan Mehmet, immediate action was taken for the Turkification-Islamization of the region. In parallel with the Turkization-Islamization process, architectural structuring has also developed. Mosques, which are among the important representatives of our cultural values, have been the most popular structures of this architectural construction. The mosques, which are shaped by climate, geography, social structure and economic factors, are generally similar, and in particular, they have some differences varying from district to district. The mosques, which were built with traditional materials and techniques for centuries, were demolished, especially since the 1960s, on the grounds that they could not meet the needs, and reinforced concrete and domed structures were built in their place. The fact that the reinforced concrete construction technique allows rapid production with low cost and less labor and workmanship has caused the disappearance of local craftsmen who know traditional materials and know the joining technique. With the understanding of the importance of historical mosques in recent times, many of the existing structures have been registered and protected by the relevant institution. These structures have been tried to be introduced with studies prepared at various times. These studies are very important in terms of revealing the general characteristics of Trabzon mosque architecture. However, while the structures built in the $18^{\text {th }}$ and $19^{\text {th }}$ centuries came to the fore in these studies, the structures of the $20^{\text {th }}$ century were ignored. Based on this information, we prepared this study in order to introduce Güneyce Mahallesi Orta Mosque and Elmaalan Mahallesi Merkez Mosque, which we think are among the last representatives of traditional Trabzon mosque architecture in terms of their characteristics, built in the 1960s, and to determine their place among other mosques in the region. In line with the purpose of the study, information was given about the general features of the traditional mosque architecture of Trabzon, and then the mosques were discussed in detail under the heading of plan and architectural features, materials-techniques, ornaments and repairs by catalog method. While the mosques, which were built by the people of the neighborhood with their own means, are similar in terms of plan, material, technique and outer coverings, their sanctuary covers and ornamental features are different. The mosques, which were built with stone materials in the masonry technique, have a simple rectangular plan extending in the north-south direction and have a four-shoulder hipped roof. The harim of Güneyce Mahallesi Orta Mosque is covered with a flat wooden ceiling, and the harim of Elmaalan Mahallesi Merkez Mosque is covered with a lath-and plaster dome. Although the mosques seem quite plain from the outside, the wooden architectural elements of Güneyce Mahallesi Orta Mosque reflect the general characteristics of the style called the Eastern Black Sea wooden style, which emerged by synthesizing classical Ottoman, baroque, rococo and Caucasian origin motifs. The mihrab of Elmaalan Central Mosque exhibits a Baroque-Rococo style character. When mosques are compared with the structures in Trabzon and different cities in terms of their features, it has been determined that they are similar in many respects. The aforementioned determinations have also proved that these mosques, which were built during the periods when reinforced concrete and domed structures began to enter our architectural life, are among the last representatives of traditional Trabzon mosque architecture.

Keywords: Turkish-Islamic Art, Trabzon, Arsin, Mosque, Masonry Stone Technique. 
Geleneksel Trabzon Cami Mimarisinin Son Temsilcilerinden İki Örnek; Arsin Güneyce Mahallesi Orta Camii ve Elmaalan Mahallesi Merkez Camii

Öz: Çalışmanın konusunu, Trabzon'un Arsin ilçesinde yer alan ve 1960'lı yıllarda inşa edilen Güneyce Mahallesi Orta Camii ile Elmaalan Mahallesi Merkez Camii oluşturur. Fatih Sultan Mehmet'in 1461 yllında Trabzon'u fethiyle birlikte bölgenin Türkleşmesi-İslamlaşması için hemen harekete geçilmiștir. Türkleşme-İslamlaşma sürecine paralel olarak mimari yapılaşma da gelişme göstermiştir. Kültürel değerlerimizin önemli temsilcileri arasında yer alan camiler, bu mimari yapılaşmanın en gözde yapıları olmuştur. İklim, coğrafya, sosyal yapı ve ekonomik etkenlerle şekillenen camiler genelde benzer, özelde ise ilçeden ilçeye değişen bazı farklılıkları bünyesinde barındırmıştır. Yüzyıllar boyunca geleneksel malzeme ve tekniklerle inşa edilen camiler, özellikle ihtiyacı karşılayamadığı gerekçesiyle1960'lı yıllardan itibaren yıkılarak yerlerine betonarme malzemeli ve kubbeli yapılar inşa edilmiştir. Betonarme yapım tekniğinin düşük maliyetle, daha az emek ve işçilikle hızlı üretime imkân vermesi, geleneksel malzemeyi tanıyan ve birleştirme tekniğini bilen yerel ustaların zamanla yok olmasına sebep olmuştur. Yakın dönemlerde tarihi camilerin öneminin anlaşılmasıyla birlikte mevcut yapıların birçoğu ilgili kurum tarafından tescil edilip koruma altına alınmıştır. Muhtelif zamanlarda hazırlanan çalışmalarla da bu yapılar tanıtılmaya çalışılmıştır. Söz konusu çalışmalar, Trabzon cami mimarisinin genel özelliklerini ortaya koyması açısından oldukça önemlidir. Ancak bu çalışmalarda 18. ve 19. yüzyıllarda inşa edilen yapılar ön plana çıkarken, 20. yüzyıl yapıları göz ardı edilmiştir. Bu bilgilerden hareketle, $1960^{\prime} l_{1}$ yıllarda inşa edilen ve sahip oldukları özellikleri açısından geleneksel Trabzon cami mimarisinin son temsilcileri arasında yer aldıklarını düşündüğümüz Güneyce Mahallesi Orta Camii ile Elmaalan Mahallesi Merkez Camii'ni tanıtmak ve bölgedeki diğer camiler arasındaki yerlerini belirlemek amacıyla bu çalışmayı hazırladık. Çalışmanın amacı doğrultusunda, Trabzon'un geleneksel cami mimarisinin genel özellikleri hakkından bilgi verilmiş olup sonrasında camiler katalog yöntemiyle plan ve mimari özellikler, malzeme-teknik, süsleme ve onarımlar başlığı altında ayrıntılı şekilde ele alınmıştır. Mahalle halkı tarafından kendi imkânlarınca yaptırılan camiler plan, malzeme, teknik ve dış örtüleri açısından benzerken, harim örtüleri ve süsleme özellikleri farklıdır. Taş malzemeyle yığma taş tekniğinde yapılan camiler, kuzey-güney doğrultuda uzayan basit dikdörtgen planlı ve dört omuz kırma çatılıdır. Güneyce Mahallesi Orta Camii'nin harimi düz ahşap tavanla, Elmaalan Mahallesi Merkez Camii'nin harimi ise bağdadi kubbeyle örtülüdür. Camiler dıştan oldukça sade görünse de Güneyce Mahallesi Orta Camii'nin ahşap mimari elemanları, klasik Osmanlı, barok, rokoko ve Kafkasya kökenli motiflerin sentezlenmesiyle ortaya çıan ve Doğu Karadeniz ahşap üslü olarak adlandırılan üslubun genel özelliklerini yansıtır. Elmaalan Merkez Camii'nin mihrabı ise Barok-Rokoko tarzı bir karakter sergiler. Camiler, sahip oldukları özellikleri açısından gerek Trabzon ilinde, gerekse farklı illerde bulunan yapılarla karşılaștırıldığında birçok açıdan benzer oldukları tespit edilmiștir. Söz konusu tespitler, betonarme malzemeli ve kubbeli yapıların mimari hayatımıza girmeye başladığı dönemlerde inşa edilen bu camilerin, geleneksel Trabzon cami mimarisinin son temsilcileri arasında yer aldıklarının da kanıtı olmuştur.

Anahtar Kelimeler: Türk İslam Sanatı, Trabzon, Arsin, Cami, Yığma Taş Tekniği. 


\section{Giriş}

A nadolu'nun önemli kentlerinden olan ve bilinen tarihi geçmişi en Aaz 4000 yıl öncesine dayanan Trabzon, konumu itibarıyla tarihin bütün evrelerinde tüm dünyanın ilgisini çekmiş ender kentlerden biridir. Coğrafi önemi ve geçiş noktasında bulunması sebebiyle tarih boyunca birçok medeniyete ev sahipliği yapmıştır. Fatih Sultan Mehmet'in 1461 yılında Trabzon'u fethiyle birlikte bölgenin Türkleşmesi-İslamlaşması için hemen harekete geçilmiştir. Türkleşme-İslamlaşma sürecine paralel olarak mimari yapılaşma da gelişme göstermiştir.

Trabzon bölgesinin kendine has coğrafi, iklimsel ve insani yapısının yansımalarını içinde barındıran camiler yörenin zengin mimari örnekleri arasında önemli yer tutar ${ }^{1}$. İstisnai örnekleri olmakla birlikte mahalle halkı tarafından yaptırılan bu camiler genellikle kuzey-güney doğrultuda uzayan basit dikdörtgen planlıdır. Örtü sistemleri dıştan dört omuz kırma çatı, içten ise ya düz ahşap tavan ya da bağdadi kubbeli düz ahşap tavandır. Taş malzemeyle yığma taş tekniğinde inşa edilen camilerin minber, vaaz kürsüsü, mahfil, pencere, kapı, tavan gibi mimari ve yapı elemanları ahşap malzemelidir. Ancak Araklı, Sürmene, of, Çaykara, Dernekpazarı ve Hayrat ilçelerinde 19. yüzyıldan kalma ahşap veya taş-ahşap (karma) malzemeyle inşa edilmiş cami örnekleri de mevcuttur. Yapılar, diştan bakıldığında sade bir görünüme sahip olsa da birçok caminin harim kısminda, malzemeye bağlı olarak oyma, kabartma, çıtakari, ajur ve kalem işi tekniğinde yapılmış bitkisel ve geometrik motif ağırlıklı süslemeler mevcuttur.

Genelde benzer, özelde ise ilçeden ilçeye değișen bazı farklılıkları bünyesinde barındıran camiler, geleneksel malzeme ve tekniklerle uzun bir süre inşa edilse de son 50-60 yıldır geleneksel mimariden kopuş belirgin biçimde gözlenmektedir. Taş ve ahşap malzemeyle inşa edilen yapılar yerini yavaş yavaş betonarme olarak inşa edilen kubbeli yapılara terk etmiştir. Düşük maliyetle, daha az emek ve işçilikle hızlı üretime imkân veren betonarme yapım tekniği, yüzlerce yıldır kendine özgü dinamiklerle olgunlaşan cami mimarisinde değişime neden olmuştur. Ayrıca geleneksel malzemeyi tanıyan, birleştirme tekniğini bilen yerel ustaların da yok olmasına yol açmıştır.

1 İsmet Çalık vd., "Doğu Karadeniz Bölgesi Tarihi Yı̆̆ma Camilerinin Restorasyonlarının Yapısal Değerlendirilmeleri”, 5. Tarihi Eserlerin Güçlendirilmesi ve Geleceğe Güvenle Devredilmesi Sempozyumu, (Erzurum: Zafer Medya Grup, 2015), 1/186. 


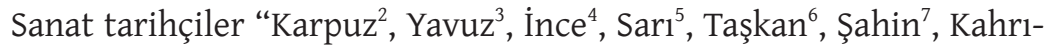
man $^{8}$ " ve mimarlar "Sümerkan - Okman", Tuluk - Durmuş ${ }^{10}$, Tuluk -Kazaz $^{11}$, Aydın - Perker ${ }^{12}$, Zorlu ${ }^{13}$, Kazaz ${ }^{14 "}$ Trabzon cami mimarisi üzerine birçok kitap, makale ve tez kaleme almıştır. Ayrıca tarafımızca hazırlanan “Trabzon ve İlçelerinde Camiler" konu başlıklı doktora tezi de bulunmak$\operatorname{tad}^{15}{ }^{15}$. Mimarlar tarafından hazırlanan çalışmalarda daha çok teknik boyut ön plana çıkarken, sanat tarihçiler her açıdan ayrıntılı bilgiler aktarmiştır.

Doktora tezi için Arsin ilçesinde yapılan saha çalışmasında 21 cami tespit edilmiş olup, bu camilerden 19'u teze dahil edilmiştir ${ }^{16}$. 1960'll yıllarda inşa edilen Güneyce Mahallesi Orta Camii ve Elmaalan Mahallesi Merkez Camii ise tezin sınırları gerekçesiyle çalışma dişında tutulmuştur.

2 Haşim Karpuz, Trabzon Merkez ve İlçelerindeki Önemli Tarihi Yapılar (Ankara: Türk Tarih Kurumu Yayınları, 2018); Hașim Karpuz, "Doğu Karadeniz Bölgesinde Bazı Ahșap Camiler”, Sanat Tarihi Araştırmaları Dergisi 34 (1989); Haşim Karpuz, "Trabzon'un Çaykara İlçesi Köylerinde Bulunan Bazı Camiler”, Vakıflar Dergisi 21 (1990); Haşim Karpuz, Trabzon (Ankara: Kültür Bakanlığı Yay1nlar1, 1990).

3 Mehmet Yavuz, Çaykara ve Dernekpazari'nda Geleneksel Köy Camileri (Ankara: Türkiye Diyanet Vakf1 Yayınları, 2009); Mehmet Yavuz, "Oslu Müderris Hac1 Hasan Efendi ve Onun Manevi Etki Alanında Olușan Mimari Yapılașma", Uluslararası Sosyal Araștırmalar Dergisi 2/7 (Bahar 2009); Mehmet Yavuz, "Doğu Karadeniz Köy Camilerinde Bezeme Anlayışı”, Uluslararası Sosyal Araştırmalar Dergisi 2/ 6 (Kış 2009); Mehmet Yavuz, "Sürmene-Gültepe Köyü Yukarı Kefeli Mahallesi Camii ve Şadırvanı”, Uluslararası Sosyal Araştırmalar Dergisi 7/31 (2014).

4 Kasım İnce, “Kabataş Köyü Merkez Camii/Çaykara/Trabzon” Vakıflar Dergisi 28 (2004).

5 Yavuz Sarı, Trabzon'un Hayrat, of ve Sürmene İlçelerindeki Köy Camileri (Samsun: Ondokuzmayıs Üniversitesi, Sosyal Bilimler Enstitüsü, Yüksek Lisans Tezi, 2016).

6 Demet Taşkan, Trabzon İli Camilerinde Ahşap Minberler (Ankara: Gazi Üniversitesi, Sosyal Bilimler Enstitüsü, Doktora Tezi, 2016).

7 Mustafa Şahin, Giresun ve Trabzon İllerindeki Bağdadi Kubbeli Camiler (Ankara: Gazi üniversitesi, Sosyal Bilimler Enstitüsü, Yüksek Lisans Tezi, 2006).

8 Ömer Kahrıman, Trabzon'daki Türk Devri Mimari Eserleri (Erzurum: Atatürk Üniversitesi, Sosyal Bilimler Enstitüsü, Yüksek Lisans Tezi, 2003).

9 M. Reşat Sümerkan - İbrahim Okman, Kültür Varlıklarıyla Trabzon-Cilt.1 İlçeler ve Köyler (Trabzon: T.C. Trabzon Valiliği ìl Kültür Müdürlüğü Yayınları, 1999).

10 Ö. İskender Tuluk - Serap Durmuş, “Araklı'nın Çok Kubbeli Camileri”, Tasarım Kültür Dergisi 208 (2007).

11 Ö. İskender Tuluk - Emriye Kazaz, “Trabzon Bölgesindeki Kırsal Cami Mimarisi Üzerine Tipolojik Bir Değerlendirme”, 1. Uluslararası Geçmişten Günümüze Trabzon'da Dini Hayat Sempozyumu, ed. Şenol Saylan - Betül Saylan (İstanbul: Değişim Yayınları, 2016), 1; Ö. İskender Tuluk - Emriye Kazaz, “Trabzon Değirmendere Vadisi'nde Geç Dönem Osmanlı Mirası: Kırsal Cami Geleneği Üzerine Bir Tipoloji Denemesi”, Osmanli'da Mimari, Sanat ve Yemek Kültürü, ed. M. Bedizel Zülfikar - Ravza Aydın (İstanbul: Mahya Yayınları, 2017), 1.

12 Hasan Aydın - Sevgen Perker, “Trabzon Uzungöl Filak Ahşap Cami Yapısal Özellikleri”, Elektronik Sosyal Bilimler Dergisi 16/63 (2017); Hasan Aydın - Sevgen Perker, “Trabzon'dan Ahşap Bir Cami Örneği: Of-Bölümlü Mithat Paşa Camii”, Journal of Hístory Culture and Art Research 6/2 (Mart 2017).

13 Tülay Zorlu, "Doğu Karadeniz Ahşap Camilerinde Restorasyon: Dernekpazarı Taşçılar Köyü Camii ve Medresesi Örneği”, Vakıflar Dergisi 32 (2009).

${ }^{14}$ Emriye Kazaz, Trabzon Kırsal Cami Mimarisi (Trabzon: Karadeniz Teknik Üniversitesi, Fen Bilimleri Enstitüsü, Doktora Tezi, 2016).

15 Yavuz Sarı, Trabzon ve İlçelerinde Camiler (Samsun: Ondokuz Mayı Üniversitesi, Lisans Üstü Eğitim Enstitüsü, Doktora Tezi, 2021).

16 Sarı, Trabzon ve İlçelerinde Camiler, 300. 
Mevcut kaynaklar incelendiğinde söz konusu camilerden Elmaalan Mahallesi Merkez Camii ile ilgili herhangi bir bilgi yoktur. Güneyce Mahallesi Orta Camii'ne ise yalnızca Kazaz'a ait doktora tezinde yüzeysel olarak değinilmiştir ${ }^{17}$. Plan, harim örtü sistemi, süsleme, malzeme ve yapım tekniği açısından Güneyce Mahallesi Orta Camii ve Elmaalan Mahallesi Merkez Camii, bölgedeki birçok tarihi cami ile benzerlik arz etmektedir. Bu sebeple geleneksel cami mimarisinin Arsin ilçesindeki son temsilcileri arasında yer aldıkları düşünülmüş ve geleneksel mimarideki yerlerinin tespiti için çalışılmaya değer bulunmuştur.

Katalog yöntemiyle hazırlanan çalışmada camiler plan ve mimari özellikler, malzeme-teknik, süsleme ve onarımlar başlığı altında ayrıntılı olarak tanıtılmıştır. Değerlendirme ve sonuç bölümünde ise sahip oldukları özellikler açısından değerlendirilip, bölgedeki tarihi camilerden örnekler verilerek benzer yanları ortaya konulmuştur.

\section{Güneyce Mahallesi Orta Camii}

Yapı, Trabzon-Arsin ilçesinin Güneyce mahallesinde bulunmaktadır. Trabzon Vakıflar Bölge Müdürlüğünce tescilli cami, mihrap kaidesi üzerinde yer alan kitabeye göre H. Irıl (1381)/M. 1961 yılında inşa edilmiştir. Doğu cephedeki harim giriş kapısının güneyine Arsin Müftülüğünce asılan bilgilendirme tabelasında inşa tarihi 1963 olarak verilmiştir. Hicri olarak yazılan inşa tarihi muhtemelen miladi takvime yanlış çevrilmiştir. Mahalle halkı tarafindan yaptırılan caminin ustası bilinmemektedir. Muhtelif dönemlerde niteliksiz müdahalelere maruz kalan yapı bugün ayakta olup ibadete açıtır.

\subsection{Plan ve Mimari Özellikler}

Mahalle yolunun kenarında yer alan cami, kuzey-güney doğrultudaki eğimli arazide, bodrum kat üzerine inşa edilmiştir. Caminin doğusunda mahalle yolu ve yapıya sonradan eklenen şadırvan, güneyinde avlu ve lojman bulunurken, batı ve kuzey yönden yamaca dayalı vaziyettedir. İnce yontu taş malzemeyle inşa edilen cami harim, mahfil ve bodrum kattan meydana gelir. Yapıda minare yoktur (Çizim 1)-(Fotoğraf 1).

Depo ve kiler olarak kullanılan bodrum kata, doğu cephe ekseninin güneyindeki dikdörtgen formlu, basık kemerli, taş söveli ve tek demir kanatlı kapıdan girilir. Bodrum kat, biri doğu cephe ekseninde, ikisi ise güney cephede olmak üzere üç pencereyle aydınlatılır. Pencereler dikdörtgen formlu, basık kemerli, taş söveli ve plastik doğramalıdır (Fotoğraf 1).

\footnotetext{
${ }^{17}$ Kazaz, Trabzon Kirsal Cami Mimarisi, 858-859.
} 
Harime girişi sağlayan kapı, doğu cephe ekseninin kuzeyinde yer alır. Söz konusu kapı, bodrum kat kapısı gibi dikdörtgen formlu, basık kemerli, taş söveli ve tek demir kanatlıdır. Doğu cephe ekseni ile kuzeydoğu köşe arasına betonarme malzemeli şadırvan eklenmiştir. Şadırvan, harim giriş kapısının önünde oldukça geniş sahanlık meydana getirmiştir. Üzeri demir ve saç malzemeyle örtülü sahanlığa, betonarme malzemeli merdivenden ulaşılır.

Caminin cephe duvarları üzerinde beşi harim katında, yedisi ise mahfil katı seviyesinde olmak üzere on iki pencere mevcuttur. Harim katındaki pencerelerin ikişer tanesi doğu ve güney cephede, biri kuzey cephede yer alırken, mahfil katı seviyesindekilerin ikişer tanesi kuzey ve güney cephede, üçü ise doğu cephededir Yamaca dayalı vaziyetteki batı cephede herhangi bir mimari unsur bulunmamaktadır. Pencerelerin tümü dikdörtgen formlu, basık kemerli, taş söveli ve plastik doğramalıdır. Mahfil katı seviyesindeki pencereler harim katındakilere göre biraz daha küçük boyutludur (Fotoğraf 1). Harim içerisine doğru genişleyerek açılan pencereler iç kısımda da aynı formunu korur.

Yapının üzeri dört omuz kırma çatı ile örtülü olup, dört cephede de kademeli olarak yukarıya doğru genişleyen yaklaşık $40 \mathrm{~cm}$ genişliğinde saçak kısmı bulunur.

Harimin kuzeyinde kare kesitli serbest iki ahşap sütunun taşıdığı mahfil vardır. Kuzeybatı köşede de ahşap malzemeyle oluşturulmuş müezzin mahfili görülür.

Güney duvar ekseninde, dikdörtgen kaideli ve taş malzemeli mihrap yer alır. Altı kademeden oluşan yarım daire formlu mihrap nişi, kademeli olarak yukarıya doğru daralmakta ve yaşmak kısmı yuvarlak kemerle sonlanmaktadır. Mihrap kaidesi güney duvardan hafif dışa taşkın vaziyettedir (Fotoğraf 2).

Mihrabın hemen batısında köprü gibi alttan geçitli forma sahip ahşap minber bulunur. On bir basamaklı minber, dikdörtgen formlu, yuvarlak kemerli giriş açıklığına sahiptir (Fotoğraf 3).

Çeyrek koni formlu ahşap vaaz kürsüsü güneydoğu köşeye yerleştirilmiştir. Kürsünün tek sıra korkuluğu vardır. Harimin üzeri düz ahşap tavanla örtülüdür (Fotoğraf 4).

Mahfil katına, kuzeydoğu köşedeki “L” formlu ahşap merdivenden ç1kılır. Kuzey duvardan harim içerisine doğu çıkıntı yapan mahfilin mihrap aksında dikdörtgen formlu mahfil köşkü bulunmaktadır. Üzeri düz ahşap tavanla örtülü mahfilin tek sira boğumlardan oluşan korkuluğu mevcuttur. Mahfil köşkünün kuzeydoğu ve kuzeybatı köşesine birer ahşap sütun 
yerleştirilmiştir. Alttan ve üstten kare, ortadan ise dairesel kesitli sütunlar tavanı taşımaktadır.

\subsection{Malzeme-Teknik}

Caminin cephe duvarlarında ince yontu, mihrabında ise düzgün kesme taş malzeme kullanılmıştır. Minber, vaaz kürsüsü, mahfil, harim ve mahfil katındaki sütunlar, mahfile çıkışı sağlayan merdiven, müezzin mahfili ve tavan ahşap malzemeden imal edilmiştir. Pencere doğramaları plastik, kapı kanatları demir, çatı örtüsü ise sac malzemelidir. Ayrıca harim duvarları, mahfilin alt yüzü ve tavan pvc lambri ile kaplıyken, dış cephe duvarları sıvanıp boyanmıştır (Fotoğraf 1-2-3-4-5).

Yapının beden duvarlarında yı̆̆ma taş, mihrap süslemelerinde kabartma, minber ve vaaz kürsüsü süslemelerinde oyma, kabartma ve ajur, mahfil süslemelerinde ise oyma tekniği uygulanmıştır.

\subsection{Süisleme}

Güneyce Mahallesi Orta Camii'nin dış cephesi oldukça sade olup, yalnızca kapı ve pencerelerin söve, kemer ve kemer kilit taşları duvar yüzeyinden hafif dışa taşırılarak cephelere hareketlilik kazandırılmıştır (Fotoğraf 1).

Harim içerisinde süsleme unsuru mihrap, minber, vaaz kürsüsü ve mahfilde görülür. Dikdörtgen formlu mihrap kaidesi paralel olarak uzayan yivli şeritlerle üç bölüme ayrılmıştır. Nişin her iki yanındaki yüzeyler aynı süsleme programina sahiptir. Alttaki bölümlerin yüzeyi dikey olarak uzayan yedişer kuşakla tezyin edilmiştir. Yanlardaki ikişer kuşak, kabartma tekniğinde yapılan yarım dairelerden, ortadaki üçü ise yine kabartma tekniğinde yapılmış yarım daire formlu silmelerden meydana gelir. Ortadaki bölümde, dikey yönlü ve dikdörtgen formlu birer pano vardır. Panoların köşelerinde yeşil, sarı, siyah, kırmızı ve mavi renkli birer yelpaze motifi bulunur. Alt ve üst köşelerdeki yelpazelerin arasına kırmızı ve yeşil renkli birer gülbezek motifi yerleştirilmiştir. Yelpaze ve gülbezek motifleri dışındaki tüm yüzey siyah, kırmızı, mavi, yeşil veya siyah renkli kalp ve stilize edilmiş lale motifleriyle bezenmiştir. Panoların iç ve dış dış kenarı, dikey olarak uzayan ikişer sıra silme ve yivle sınırlandırılmıştır. Üstteki bölümü oluşturan yivli şeritler, mihrap nişinin yaşmak kısmını üç yönden çevreleyerek uzanmaktadır. Söz konusu bölümün yüzeyi de kabartma tekniğinde yapılmış yeşil, siyah, mavi veya kırmızı renkli koçboynuzu ve stilize lale motifleriyle doldurulmuştur. Bu bölümün üst kısmında birer satırlık iki yazı vardır. Soldaki yazıda kabartma tek-

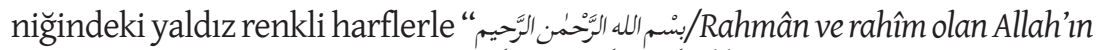

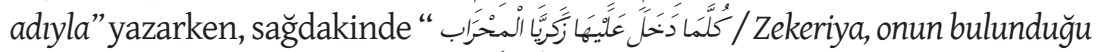
bölmeye her girişinde (Âl-i İmrân 37)” yazar. Yazıların arasında kırmızı, mavi ve 
sarı renkli iki gülbezek motifi, gülbezeklerin arasında ise yarım güneşe benzer bir motif görülür. Mihrap nişinin kademeleri paralel olarak uzayan mavi ve kırmızı renkli ikişer silmeyle birbirinden ayrılmıştır. Kademelerin yüzeyi yeșil zemin üzerine yapılmış farklı renklerdeki nokta benzeri motiflerle hareketlendirilmiştir. Ayrıca her bir kademeden beyaz ve siyah renkli perde motifleri asılmaktadır. Niş yaşmağında, üzerinde yaldız renkli ay yıldız motifi bulunan mavi renkli ve oval formlu kabara mevcuttur. Yaşmağın alt ucunda, tek sıra halinde paralel olarak uzayan mavi, kırmızı ve yeşil renkli testere ağzı motifi vardır. Niş kademelerinin her iki yanında kabartma tekniğinde yapılmış yaldız renkli yelpaze ve kıvrım motifleri, yaşmağın her iki yanında ise kırmızı ve yeşil renkli ikişer kupa motifi yer alır. Yaşmak üzerinde kırmızı ve yaldız renkli papatya motifi bulunur. Papatya motifinin üzerindeki yüzey, hafif çökertilerek kare formlu çerçeve meydana getirilmiştir. Çerçevenin alt köşelerinde yeşil, üst köşelerinde ise kırmızı renkli birer yelpaze motifi görülür. Çerçeve yüzeyi, yüzü aşağı doğru bakan yaldız renkli ay yıldız motifiyle ve mavi-kırmızı renkli iki papatya motifiyle hareketlendirilmiştir. Söz konusu çerçevenin her iki yanında yaldız çerçeveli birer yazı madalyonu yer alır. Sağ

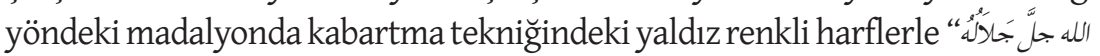

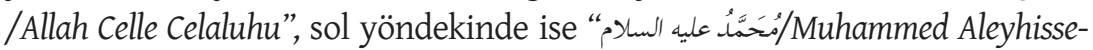
lam" yazar. Madalyonların altında mavi, yeşil ve sarı renkli kıvrım ve baklava formları vardır. Mihrap kaidesinin saçak kısmı hafif dışa taşkın şekilde olup yüzeyi yarım silindir formlu yivlerle hareketlendirilmiştir. Ayrıca saçak yüzeyine, kare formlu kabaralar ve yapının kitabesi yerleştirilmiştir. Kabaralar, atlamalı olarak sarı ve yeşil renklere boyalıdır. Dikey yönlü ve dikdörtgen formlu kitabenin ortasında kırmızı renkli madalyon görülür. Madalyonun üzerinde, kabartma tekniğindeki mavi renkli rakamlarla caminin inşa tarihi olan “|rл /1381" yazarken, her iki yanında yaldız renkli birer minare motifi bulunmaktadır. Saçak altındaki yüzeyin her iki ucunda kırmızı renkli birer ay yıldız, ortasında ise yaldız renkli rozet yer alır. Söz konusu rozet kalkık kemerli çerçeve içerisine alınmıştır (Fotoğraf 2).

Minberin her iki yüzü de aynı süsleme programına sahiptir. Üçgen formlu yan aynalıklar, ortada kalp şekli oluşacak şekilde yerleştirilen yeşil, siyah, kırmızı veya bordo renkli "S" formundaki kıvrımlarla bezenmiştir. Kalp formundaki motiflerin arası sarı veya mavi renkli yivlerle doldurulmuştur. Aynalıklardan minber gövdesi boyunca üç sırsa süsleme şeridi uzanır. Şeritlerden altta ve üstte olanı mavi, yeşil, sarı veya siyah renkli yaprak benzeri motiflerden, ortada olanı ise yeşil ve mavi renkli yaprak motiflerinden meydana gelir. Alttaki şeridin güney ucuna farklı renklerden oluşan rozet motifi yerleştirilmiştir. Minber aynalıklarının altındaki yüzey çökertilerek mavi çerçeveli dört dikdörtgen pano elde edil- 
miştir. Üstteki panoların ortasında, bordo renkli dairesel form içerisine yerleştirilmiş sarı ve mavi renkli birer çiçek motifi, köşelerinde ise yeşil veya bordo renkli birer çeyrek rozet bulunur. Alttaki panoların içerisinde ise mavi ve bordo renkli dairesel form içerisine yerleştirilmiş ikişer çiçek yer alır. Panolar dışında kalan tüm yüzey sarı, siyah ve beyaz renkli dama motifiyle doldurulmuştur. Ajur tekniğinde yapılan tek sıra minber korkuluğu mavi ve bordo renkli "S" formundaki kıvrım dal motifinden meydana gelir. Korkulukla girişin birleştiği noktalara, turuncu ve mavi renkli yelpaze formunda birer ahşap köşebent yerleştirilmiştir. Girişin yan yüzleri sarı, mavi ve yeşil renkli ok ucu motifleriyle tezyin edilmiştir. Söz konusu motifler, siyah renkli yapraklarla birbirinden ayrılır. Köşk açıklıklarının altında, aşağıdan yukarıya doğru kalp şekli oluşturacak şekilde uzayan yeşil renkli "S" formları bulunur. Kıvrımların oluşturduğu kalp formundaki boşluklarda mavi, siyah, bordo veya sarı renkli birer yaprak motifi yer alır. Köşk açıklıkları, üstten ve alttan yuvarlak kemer formludur. Kemerlerde yeşil, kırmızı veya mavi renkli koçboynuzları mevcuttur. Köşk desteklerinin yüzeyi, "S" formunda yukarıya doğru uzayan yeşil renkli kıvrımlarla bezenmiştir. Köşkün beyaz renkli kemer köşelikleri, farklı renklerdeki nokta benzeri motiflerle hareketlendirilmiştir. Köşk üzerindeki külah, çokgen formlu kasnak üzerine oturur. Kasnağın her bir köşesi atlamalı olarak bordo ve mavi renklere boyalıyken, külah yüzeyi nokta benzeri motiflerle süslenmiştir. Giriş açıklı̆̆ının ön yüzünde de, yan yüzlerdeki gibi ok ucu motifleri bulunur. Giriş kemerinde, sarkıt şeklinde yeşil ve sarı renkli altı tane silindir motifi bulunmaktadır. Kemer kavsi dıştan, atlamalı olarak sıralanan mavi ve kırmızı renkli iki sıra noktalarla çevrilidir. Her iki yönden sarı ve siyah renkli dama motifiyle sınırlandırılan kemer köşeliklerinde, yeşil renkli dairesel form içerisine yerleştirilmiş yeșil ve mavi renkli birer rozet motifi mevcuttur. Giriş üzerindeki aynalıkda, dairesel formlu iki açıklık görülür. Açıklıkların içerisi, ajur tekniğinde yapılmış birer çiçek motifi ile doldurulmuştur. Söz konusu çiçek motifleri, düğüm yaprak uzayan kıvrımdan meydana gelir. Aynalık, sarı ve siyah renkli dama motifiyle üç yönden çevrilidir. Minber, ajur tekniğinde yapılmış tepeliğe sahiptir. Tepeliğinin ortasında, iç içe geçmiş iki dairesel form görülür. Dairesel formlardan dıştaki beyaz, içteki ise yeşil çerçevelidir. İçteki dairesel formun içerisi, düğüm yaparak uzayan kıvrımın meydan getirdiği çiçek motifiyle doldurulmuştur. Her iki dairesel form arasında kalan yüzey, mavi renkli papatya yaprağına benzer motiflerle bezenmiştir. Söz konusu motiflerin her birinin içerisine, beyaz renkli mızrak ucuna benzer birer motif yerleştirilmiştir. Dıştaki dairesel form yeşil ve kırmızı renkli noktalarla çevrilidir. Etrafı yaprak benzeri motif- 
lerle çevrili dairesel formların üzerinde yine benzer şekilde bir dairesel form, onun üzerinde ise siyah renkli stilize edilmiş lale motifi mevcuttur (Fotoğraf 3). Bahsi geçen minber, Arsin "Güneyce Mahallesi Büyük Camii (1882-83)" minberiyle neredeyse aynı özelliklere sahiptir.

Vaaz kürsüsünün yüzeyi, dikey yönlü uzayan ince çıtalarla on bir eşit parçaya bölünmüştür. Aşağıdan yukarıya doğru genişleyen bölümler, üstten mavi renkli zikzak motifiyle, alttan ise yeşil ve sarı renkli halat motifiyle sınırlandırılmıştır. Aynı süsleme programına sahip bölümlerin içerisinde, üst üste konumlandırılmış motifler görülür. Motifler, aşağıdan yukarıya doğru sırasıyla yaprak, vazodan çıkan yaprak, koçboynuzu ve kalp oluşturacak şekilde konumlandırılan "S" formlu kıvrımlardan meydana gelir. Motiflerin her biri mavi, yeşil, kırmızı, sarı, kahve ve siyah renklere boyanarak kürsü yüzeyine canlılık kazandırılmıştır. Ajur tekniğginde yapılmış kürsü korkuluğunun yüzeyi, dikey yönlü ve sarı renkli ikişerli çıtalarla yedi çerçeveye ayrılmıştır. Çerçevelerin içerisinde birer baklava form bulunur. Baklava formlarının her bir köşesine ve içerisine virgüle benzer motifler yerleştirilmiştir. Korkuluk üstten paralel olarak uzayan sarı ve mavi renkli zikzak motifleriyle sınırlandırılmıștır (Fotoğraf 4).

Mahfilin ön yüzünde paralel olarak uzayan iki sıra süsleme kuşağı vardır. Kuşaklardan altta olanı kabartma tekniğinde yapılmış yarım silindir formlu yivlerden, üstte olanı ise oyma tekniğinde yapılmış yivlerden meydana gelir. Üstteki şerit mahfil köşkü boyunca da uzanmaktadır. Köşkün alt kenarında, sarkıt şeklinde bir kuşak da mevcuttur. Söz konusu kuşak atlamalı olarak mavi ve kırmızı renklere boyanan yarım dairelerden oluşur. Mahfil korkuluğundaki boğumların her iki ucu kırmızıya, orta kısımları ise yeşile boyanarak mahfile hareketlilik kazandırılmıştır (Fotoğraf 5).

\subsection{Onarimlar}

Vakıflar Bölge Müdürlügü̈nün arşiv kayıtlarında yapı ile alakalı herhangi bir onarım kaydı bulunmamaktadır. Ancak yapmış olduğumuz incelemelerde muhtelif zamanlarda yapılmış bazı müdahaleleri gözlemledik. Söz konusu müdahaleler şöyledir;

$>$ Orijinalinde ahşap olan kapı kanatları demir malzemeyle, pencere doğramaları ise plastik malzemeyle değiştirilmiştir.

$>$ Kiremit malzemeli çatı örtüsü kaldırılıp sac malzemeyle kaplanmiştır.

$>$ Harim duvarları, tavan ve mahfilin alt yüzü niteliksiz pvc lambri ile kaplanmıştır.

> Mahfile çıkışı sağlayan merdiven ahşap lambri ile kaplanmıştır.

$>$ Cephe duvarları sıvanıp boyanmıștır. 


\section{Elmaalan Mahallesi Merkez Camii}

Yap1, Trabzon-Arsin ilçesinin Elmaalan mahallesinde bulunmaktadır. Caminin muhtelif yerlerinde dört kitabe görülür. Kuzey cephe eksenindeki harim giriş kapısı üzerinde yer alan dikdörtgen formlu mermer kitabede;

\section{"Elmaalan Camii}

Y. Tarihi 1964”, söz konusu kapının kaidesi üzerinde duvar içerisine gömülmüş vaziyetteki kare formlu mermer kitabede;

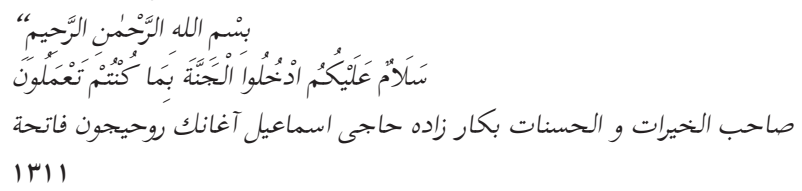

Rahmân ve rahîm olan Allah'in adıyla

Selâm size; yaptıklarınıza karşılık girin cennete! (Nahl 32)

Sahib-ül hayrat vel-hasenat bekarzade Hacı İsmail Ağa'nın ruhu için fatiha

1311”, mihrap nişinin üzerindeki kitabede "Irvq" yazarken, mihrap kaidesi üzerindeki kitabede;

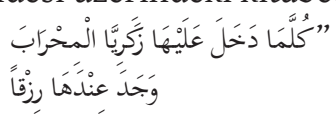

Senei 1311"

Zekeriyyâ onun bulunduğu yere, mâbeddeki odaya her girdiğinde yanında (yeni) bir rızık bulur (Âl-i İmrân 37)” yazar. Hicri olarak yazılan "ı rı" tarihini miladi takvime çevirdiğimizde "1894”, “ı rv" tarihini çevirdiğimizde ise “1960” ı rva/M.1960” tarihinin inşa sürecinin başladığı, giriş kapısı üzerindeki "1964" tarihinin ise ibadete açılış tarihi olduğunu söyleyebiliriz. Giriş kapısı üzerinde, cephe duvarına gömülü vaziyetteki "H. 1r। /1894" tarihli kitabe ise mevcut caminin yaklaşık 50 m yukarısında bulunan ancak günümüzde olmayan eski camiye aittir. Mahalle halkı tarafından yaptırılan caminin ustası bilinmemektedir. Muhtelif dönemlerde müdahalelere maruz kalan yapı bugün ayakta olup ibadete açıktır.

\subsection{Plan ve Mimari Özellikler}

Mahalle yolunun kenarında yer alan cami, kuzey-güney doğrultudaki eğimli arazide taş kaide üzerine oturmaktadır. Yapının kuzeyinde ve doğusunda mahalle yolu, batısında ve güneyinde ise hazire vardır. Taş malzemeyle inşa edilen yapı, harim ve mahfil katından meydana gelir. Camiye 1970'li yıllarda eklenen minare, batı cephenin kuzey köşesine yakın bir noktada yapıya bitişik olarak konumlandırılmıştır (Çizim 2)-(Fotoğraf 6).

Cami, biri kuzey cephe ekseninde, diğeri ise doğu cephenin kuzey kö- 
şesine yakın bir noktada olmak üzere iki giriş kapısına sahiptir. Her iki kapı da dikdörtgen formlu, yuvarlak kemerli, taş söveli ve iki ahşap kanatlıdır. Kuzey cephe eksenindeki ana giriş kapısı, cephe yüzeyinden hafif dışa taşırılan dikdörtgen formlu kaide içerisine yerleştirilmiştir. Cami eğimli arazi üzerine inşa edildiği için söz konusu kapıya çift yönlü merdivenden ulaşılır (Fotoğraf 7).

Cephe duvarlarında, sekizi harim katında, dokuzu ise mahfil katı seviyesinde olmak üzere on yedi pencere vardır. Pencerelerin tümü dikdörtgen formlu, yuvarlak kemerli, taş söveli, plastik doğramalı ve demir parmaklıklıdır. Mahfil katı seviyesindeki pencereler, harim katındakilere göre daha küçük boyutludur (Fotoğraf 6). Harim içerisine doğu genişleyerek açılan pencereler iç kısımda da aynı formunu korur.

Yapının üzeri dört omuz kırma çatı ile örtülü olup, dört cephede de yaklaşık $50 \mathrm{~cm}$ genişliğinde dışa taşkın saçak kısmı bulunur.

Batı cephenin kuzey köşesine yakın bir noktada yapıya bitişik olarak konumlandirılan minare, sekizgen kaideye, çokgen formlu gövdeye ve tek şerefeye sahiptir. Kaideden gövdeye geçiş soğan pabuçla sağlanır.

Harimin kuzeyinde, kare kesitli serbest iki ahşap sütunun taşıdığı mahfil görülür. Kuzeybatı köşede ise ahşap müezzin mahfili yer alır.

Dikdörtgen kaideli ve taş malzemeli mihrap, güney duvar eksenine yerleştirilmiştir. Altı kademeden oluşan yarım daire formlu mihrap nişi, kademeli olarak yukarıya doğru daralmakta ve yaşmak kısmı yuvarlak kemerle sonlanmaktadır (Fotoğraf 9).

Orijinal olmayan ahşap minber güneybatı köşeye, vaaz kürsüsü ise güneydoğu köşeye yerleştirilmiştir. Harimin üzeri bağdadi kubbeyle örtülüyken kubbe dışında kalan kısımlar düz ahşap tavanla örtülüdür (Fotoğraf 10). Düz ahşap tavan, cami imamının ifadesine göre Karaca (Garon) Mahallesi sakinlerinden Hüseyin usta tarafından yenilenmiştir (12. 03. 2021).

Mahfil katına, kuzeybatı köşedeki "L” formlu ahşap merdivenden çıkılır. Mahfil, kuzey duvardan harim içerisine doğru üç yerden dalgalı olarak girinti yapar. Üzeri düz ahşap tavanla örtülü mahfilin yaklaşık 60 cm yüksekliğinde korkuluğu mevcuttur. Mahfil katında, mahfili taşıyan sütunlarla aynı hizada konumlandırılmış iki serbest sütun bulunur. Kare kesitli ahşap sütunlar tavanı taşımaktadır.

\subsection{Malzeme-Teknik}

Yapının üzerine oturduğu kaidede ince yontu, kuzey ve doğu cephe duvarlarıyla birlikte mihrapta düzgün kesme, batı ve güney cephe duvarlarında ise kaba yontu taş malzeme kullanılmıştır. Minber, vaaz kürsüsü, 
mahfil, harim ve mahfil katındaki sütunlar, mahfile çıkışı sağlayan merdiven, düz tavanlar ve kapı kanatları ahşap malzemeden imal edilmiştir (Fotoğraf 8-9-10). Pencere doğramaları plastik, parmaklıkları demir, bağdadi kubbe ahşap ve alçı, minare ise betonarme malzemelidir (Fotoğraf 6-10). Ayrıca harim duvarları ile batı ve güney cephe sıvanıp boyanmıştır (Fotoğraf 6-8).

Caminin cephe duvarlarında yığma taş, harim giriş kapılarındaki süslemelerde oyma, kuzey cephedeki kapı kaidesinde kabartma, mihrapta oyma ve kabartma, harim duvarlarında ve bağdadi kubbede kalemişi, düz ahşap tavanda ise çıtakari tekniği uygulanmıştır (Fotoğraf 6-8-9-10).

\subsection{Süsleme}

Diş cephe oldukça sade olup pencerelerin söve ve kemeri, duvar yüzeyinden hafif dışa taşırılarak cephelere hareketlilik kazandırılmıştır. Kuzey cephede yer alan harim katındaki pencerelerin kemer kilit taşı, yarım silindir formunda aşağıya doğru sarkmaktadır (Fotoğraf 6). Yine bu cephedeki harim giriş kapısı, tek sıra halinde uzayan baklava formlarıyla üç yönden çevrelenmiştir. Kabartma tekniğinde yapılan formların her biri iç içe geçmiş ikişer motiften meydana gelir. Kapı kaidesinin saçağı, kademeli olarak yukarıya doğru genişleyen silmelerden oluşur (Fotoğraf 7).

Kuzey ve doğu cephedeki kapıların kanatları aynı süsleme programına sahiptir. Kanat yüzeyleri çökertilerek üst üste konumlandırılmış panolar elde edilmiștir. Altta ve üstte bulunan dikey yönlü ve dikdörtgen formlu panolar farklı tarzdaki kıvrımlarla doldurulmuştur. Ortadaki kare formlu panoların içerisi ise iç içe geçmiş halkaların oluşturduğu çiçek benzeri motifle tezyin edilmiştir. Kanat yüzeyleri kahverengine, panolar ise pembe renge boyanarak kapılara canlılık kazandırılmıştır (Fotoğraf 7).

Harim içerisindeki süslemeler mihrapta, tavanda ve duvarlarda görülür. Mihrap nişi, iki sıra süsleme şeridiyle üç yönden çevrilidir. Şeritlerden dışta olanı silmelerden, içte olanı ise saç örgü motifi oluşturarak uzayan kıvrım dallardan oluşur. Örgü motifinin içte oluşturduğu boşluklarda, atlamalı olarak yerleştirilmiş yaprak ve çiçek motifleri bulunur. Mihrap nişinin kenar hatları, üzerinde yaprak ve çiçek olan "S" formlu kıvrım dal motifiyle, kavsaranın kenar hatları ise " $\mathrm{S}$ " ve " $\mathrm{C}$ " formlarıly belirginleştirilmiştir. Niş yüzeyi, aşağıdan yukarıya doğru uzayan yivlerle, kavsara ise uçları volütlü " $\mathrm{S}$ " ve "C" formlarıyla tezyin edilmiştir. Niş yaşmağına, dışa taşkın vaziyette olan yaprak motifi yerleştirilmiştir. Yaprak motifinin alt yüzünde halka oluşturulmuş ve oluşturulan halkaya yuvarlak formlu kabara asılmıştır. Söz konusu yaprak motifinin her iki yanında ç-kan birer kıvrım dal, niş kavsarasının yanlarından aşağı doğru sarkmak- 
tadır. Kıvrım dalların üzerinde yaprak ve çiçek motifleri mevcuttur. Niş üzerinde, kalın silmeyle oluşturulmuş dikdörtgen formlu yazı panosu yer

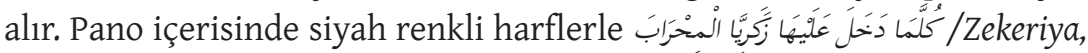
onun bulunduğu bölmeye her girişinde (Âl-i İmrân 37)" yazar. Nişi çevreleyen dıştaki silmeler, orta da kısımda yukarı doğru çıkıntı yaparak dikdörtgen formlu pano meydana getirmiştir. Panonun ortasındaki hafif dişa taşkın taşın üzerinde palmet benzeri motif görülür. Taşın yüzeyinde, kabartma tekniğindeki siyah renkli harflerle "Irva/1379" yazılıdır. Taşın sağında,

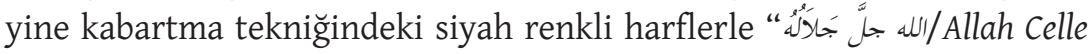
Celaluhu" yazarken, solunda "محمد عليه السلام/Muhammed Aleyhisselam" yazar. Mihrap nişini çevreleyen silmelerin sağ ve sol üst köşelerinin üzerine, kademeli olarak yukarıya doğru genişleyen kare kesitli birer başlık yerleştirilmiştir. Başlıklar, paralel olarak uzayan silmelerle birbirine bağlıdır (Fotoğraf 9).

Bağdadi kubbenin ortasında, iç içe geçmiş beyaz çerçeveli üç dairesel form mevcuttur. İçteki dairesel formun yüzeyi, çiçek motifiyle bezelidir. İçteki dairesel formlar arasında kalan lacivert renkli yüzeyde, Fatiha suresinin bir kısmı yazılıyken, dıştaki dairesel formlar arasında kalan yüzey, beyaz renkli bitkisel motiflerle doldurulmuştur. Söz konusu dairesel formlar, kahve ve siyah çizgilerle oluşturulan on dilimli kemer formuyla dıştan çevrilidir. Uçlarına kahve renkli birer palmet yerleştirilen kemerlerin içerisi, kahve zemin üzerine beyaz renkli yapılmış bitkisel motiflerle bezelidir. Her bir dilimli kemerden kubbenin dış kenarına doğru kahve renkli ve bitkisel desenli birer şemse uzatılarak kubbe süslemesi tamamlanmıştır. Kubbe dışında kalan düz ahşap tavanın yüzeyi, sırt sırta ve yüz yüze bakacak şekilde çakılan "C" formlarıyla kareye benzer alanlara bölünmüştür. Gerek düz ahşap tavan, gerekse bağdadi kubbe, tek sıra halinde uzayan ve oyma tekniğinde yapılan kıvrım dalla dıştan çevrilidir. Ayrıca bağdadi kubbenin kenarında, tek sıra boğumlardan oluşan korkuluk görülür (Fotoğraf 10).

Harim katındaki pencerelerin her iki yanında, aşağıdan yukarıya doğru uzayan birer süsleme kuşağı bulunur. Kuşaklar, kahve zemin üzerine beyaz renkle yapılan bitkisel motiflerden meydana gelir. Söz konusu kuşakların her iki ucunda, sağa ve sola doğru uzayan yine kahve renkli kıvrım dallar görülür. Doğu ve batı duvardaki pencerelerin arasına, turuncu ve siyah çizgili birer şemse yerleştirilmiştir. Şemselerin içerisi, kahve zemin üzerine beyaz renkle yapılmış bitkisel motiflerle bezelidir. Mahfil katı seviyesindeki pencerelerin her iki yanında, kalem işi tekniğiyle yapılmış birer burmalı sütun vardır. Kahve ve beyaz renklerle oluşturulan sütunların ucundan çıkıp sağa ve sola doğru uzayan turuncu renkli yaprak ve 
çiçek motifleri bulunur. Doğu, batı ve güney duvarda yer alan mahfil katı seviyesindeki pencerelerin arasına madalyonlar yerleştirilmiştir. Madalyonların içerisinde, mavi zemin üzerine sarı renk harflerle yazılmış yazılar yer alır. Batı duvardaki madalyonlarda kuzeyden güneye doğru sıra-

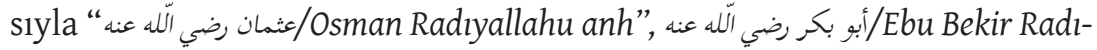

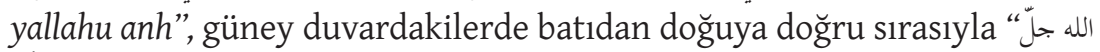

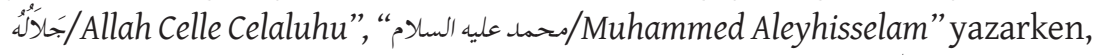

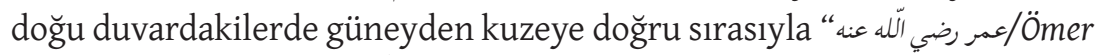
Radiyallahu anh” ve “على رضي الله عنه/Ali Radiyallahu anh” yazar. Madalyonlar, palmet benzeri kahve renkli bitkisel motiflerle diștan çevrilidir. Harim ve mahfil katı seviyesindeki pencereler, mavi zemin üzerine sarı renk harflerle yazılmış yazı kuşağıyla birbirinden ayrılmıştır. Batı, güney ve doğu duvar boyunca uzayan kuşakta “Esmâül Hüsnâ" yazar (Fotoğraf 8).

\subsection{Onarimlar}

Tescilli olmayan yapı ile ilgili arşiv kayıtlarında onarım kaydı bulunmamaktadır. Ancak caminin emekli imamı, minarenin 1970'li yıllarda eklendiğini ve 1995-96 yıllarında bir dizi onarımın yapıldı̆̆ını ifade etti (12. 03. 2021). Söz konusu onarımda yapılan müdahaleler şöyledir;

> Harimdeki sütunlar ve mahfil korkuluğu ahşap lambri ile kaplanmiş.

> Ahşap pencere doğramaları plastik malzemeyle değiştirilmiş ve pencere denizlikleri yenilenmiş.

Çökme sebebiyle bağdadi kubbe onarılarak desteklenmiş.

Ayrıca camide yapmış olduğumuz incelemelerde, batı ve güney cephenin sıvanıp boyandığını, orijinalinde kiremit olan çatı örtüsünün saç malzemeyle değiştirildiğini, ahşap minber ve vaaz kürsüsünün yakın dönemde eklendiğini, düz ahşap tavanın yenilendiğini, harim duvarlarında ve bağdadi kubbede yer alan kalemişi süslemelerin yakın dönemde yapıldığını gözlemledik.

\section{Değerlendirme ve Sonuç}

Trabzon'un kırsal bölgelerinde, 17. yüzyıldan itibaren artan Müslüman nüfus sayısına paralel olarak camilerin sayısı da artmıştır. Erken dönemlerde inşa edilen camiler birkaç mahalleye hizmet edebilecek noktalarda konumlandırılırdi $^{18} .20$. yüzyıla gelindiğinde ise gerek Müslüman nüfus oranının, gerekse imkânların artmasıyla mahallelerde bir veya birden faz-

\footnotetext{
${ }^{18}$ Necmettin Aygün, Of Kazası'nda Dini Yapılar ve Görevlileri (1691-1833)-(Of'un İskân Tarihine Hurufat Kayıtlarının Katkısl) (Ankara: Serander Yayınları, 2021), 69.
} 
la cami inşa edilmiştir. Söz konusu etkenlerle birlikte, mahalli yerleşimlerin kuzey-güney doğrultuda uzayan vadilerin her iki yakasında dağınık şekilde konumlanmasının da birden fazla cami inşasını zorunlu kıldığını düşünüyoruz. Çalışmamıza konu olan ve 20. yüzyılın üçüncü çeyreğinde inşa edilen Güneyce Mahallesi Orta Camii ve Elmaalan Mahallesi Merkez Camii'nin bulunduğu mahallelerde de birden fazla cami vardır.

Bölge coğrafyası dağlık olduğu için camilerin büyük çoğunluğu ya taş kaide üzerine ya da bodrum kat üzerine inşa edilmiştir. Bodrum katlar genellikle depo, mektep, imam odası gibi amaçlar için kullanılmıştır. Güneyce Mahalle Orta Camii bodrum kat üzerine, Elmaalan Mahallesi Merkez Camii ise taş kaide üzerine oturan camiler arasındadır. Bodrum kata sahip camilere Arsin Nuroğlu Mahallesi Camii (1941), Çubuklu Mahallesi Merkez Camii (1954), Karaca Mahallesi Camii (1955), Dernekpazarı Ormancık Mahallesi Merkez Camii (1892) ${ }^{19}$, Rize Ardeşen Doğanay Köyü Camii (1897-98) ${ }^{20}$, Hemşin Bilenköy Camii (18. yy.) ${ }^{21}$, Giresun-Çaldağ Melikli Mahallesi Tahtalı Camii (18. yy. ikinci yarısı) ${ }^{22}$, Artvin Muratlı Merkez Camii (1847) ${ }^{23}$, Borçka Düzköy Camii (1850) ${ }^{24}$ ve Borçka Camili (Macahel) Köyü Camii'ni (1855 ?) $)^{25}$ örnek verebiliriz. Arsin Atayurt Mahallesi Merkez Camii (1899), Güneyce Mahallesi Mandıra Camii (1925), Araklı Turnalı (Os) Mahallesi Camii (1841-42) ${ }^{26}$, of Bölümlü Mithat Paşa (Kalanas) Mahallesi Camii (1846) ${ }^{27}$, Çaykara Kabataş Mahallesi Merkez Camii (1811), Çorum Üçköy Köyü Camii (1897) ${ }^{28}$, Tavukçuhoca Camii ${ }^{29}$, Amasya Kızılkışlacık Köyü Camii $(1865)^{30}$, Kastamonu Talipler Köyü Rüstem Paşa Camii

19 Yavuz, Çaykara ve Dernekpazarı'nda Geleneksel Köy Camileri, 106.

${ }^{20}$ Muhammet Özkurt, Rize Ahșap Camilerinde Süsleme (Karabük: Karabük Üniversitesi, Lisansüstü Eğitim Enstitüsü, Yüksek Lisans Tezi, 2020), 28.

${ }^{21}$ Özkurt, Rize Ahşap Camilerinde Süsleme, 43.

${ }^{22}$ Eyüp Nefes, "Giresun'da Yeni Tespit Edilen Bir ahşap Cami; Çaldağ Beldesi Melikli mahallesi Tahtalı Camii”, Dinbilimleri Akademik Araștırma Dergisi 9/2 (2009), 202.

${ }^{23}$ Osman Aytekin, "Serhat Boylarında Bir Osmanlı Dönemi Yapısı Muratlı Merkez Camii”, Güzel Sanatlar Enstitüsü Dergisi 4 (1998), 38.

${ }^{24}$ Rümeysa Coşkun - Banu Çelebioğlu, “Artvin Borçkadaki Yığma Ahşap Camiler”, bâb Mimarlık ve Tasarım Dergisi 1/2 (2020), 152.

${ }^{25}$ Demet Taşkan, Artvin İli Borçka ve Hopa İlçeleri Camilerinde Ahşap Süslemeler (Ankara: Gazi Üniversitesi, Sosyal Bilimler Enstitüsü, Yüksek Lisans Tezi, 2011), 112.

${ }^{26}$ Yavuz, "Oslu Müderris Hacı Hasan Efendi ve Onun Manevi Etki Alanında Oluşan Mimari Yapılaşma”, 268.

${ }^{27}$ Aydın - Perker, “Trabzon'dan Ahşap Bir Cami Örneği: Of-Bölümlü Mithat Paşa Camii”, 462.

${ }^{28}$ Çiğdem Karaçay, “Çorum Üçköy Köyü Camii: Mimari ve Süsleme Özellikleri”, Hitit Üniversitesi Sosyal Bilimler Enstitüsü Dergisi 12/2 (2019), 523.

${ }^{29}$ Eyüp Nefes - Recep Gün, “Çorum/İskilip’te Çantı Tekniğinde İnşa Edilmiş İki Cami: Sanayi Marangozlar ve Tavukçuhoca Camileri”, Hitit Üniversitesi İlahiyat Fakültesi Dergisi 15/30 (2016), 307.

${ }^{30}$ Fazilet Koçyiğit, “Amasya'da Ahşap Tavanlı İki Cami Örneği: Şıhlar ve Kızılkışlacık Köyü Camileri”, MANAS Sosyal Araştırmalar Dergisi 8/2 (2019), 1647. 
(1530'lar) ${ }^{31}$, Samsun-Kavak Alagömlek Köyü Rahmioğlu Mahallesi Camii ${ }^{32}$, Kars Bekler Köyü Camii (1948-49) ${ }^{33}$ ile Yücelen Köyü Camii (1950) ${ }^{34}$ ise taş kaide üzerine oturan camilerden bazılarıdır.

Kırsal bölgelerdeki camilerin inşasında taş malzeme ön plana çıksa da Araklı, Sürmene, of, Hayrat, Dernekpazarı ve Çaykara ilçelerinde ahşap veya taş-ahşap (karma) malzemeyle inşa edilmiş örneklerde mevcuttur ${ }^{35}$. Günümüzde Trabzon il sınırları içerisinde ahşap veya taş-ahşap (karma) malzemeyle inşa edilmiş 16 cami bulunmaktadır. Söz konusu camiler 19. yüzyıldan kalmadır. Erken dönemlerde inşa edilen mescit fonksiyonlu ilk yapıların ahşap malzemeyle yapıldığı bilinmektedir ${ }^{36}$. Ancak bu yapılar zamanla ihtiyacı karşılayamaması ve ahşabın dayanıksız malzeme olması sebebiyle taş malzemeli olarak yenilenmiştir. Taş malzemeli cami inşası 1960'l y yllara kadar aralıksız devam etmiștir. 60'lı yıllardan itibaren ise betonarme malzemeyle inşa edilmiş kubbeli camiler ön plana çıkmaya başlamıştır. Ekonomik, ulaşım gibi imkânların gelişmesiyle birlikte, ihtiyacı karşılayamadığı gerekçesiyle taş malzemeli yapıların çoğu da yavaş yavaş betonarme olarak yenilenmiştir. İncelemiş olduğumuz Güneyce Mahallesi Orta Camii ve Elmaalan Mahallesi Merkez Camii, Arsin ilçesinde taş malzemeyle, yı̆̆ma taş tekniğinde inşa edilmiş son yapılar arasında yer alır. Yığma taş tekniğinde inşa edilen camilere Arsin Yeşilce Mahallesi Konak Camii (1822), Güneyce Mahallesi Büyük Camii (1882-83), Atayurt Mahallesi Merkez Camii (1899, Gölgelik Mahallesi Camii (1904), Güneyce Mahallesi Mandıra Camii (1925), Nuroğlu Mahallesi Camii (1941), Karaca Mahallesi Camii (1955), Işıklı Mahallesi Yeni Camii (1956), Çiçekli Mahallesi Merkez Camii (1956), Cudibey Mahallesi Orta Camii'dir (1958), Akçaabat Dürbinar Mahallesi Camii (1746), Orta Mahalle Merkez Camii (1800), Araklı Merkez Büyük Camii (1902) ${ }^{37}$, Hayrat Sarmaşık Mahallesi Camii (1877) ${ }^{38}$, Ortahisar (Merkez) Gülbahar Hatun Camii (1514) ${ }^{39}$, İskender Paşa Camii'ni (1529) ${ }^{40}$, Artvin Salih Bey (Çayağzı) Camii (1792) ${ }^{41}$, Rize

${ }^{31}$ N. Çiçek Akçıl Harmankaya, “Kastamonu Talipler Köyü Rüstem Paşa Camii”, History Studies 11/4 (2019), 1261.

32 Eyüp Nefes - Recep Gün, “Samsun/Kavak'ta Çantı Tekniğinde İnşa Edilen Alagömlek Köyü Rahmioğlu Mahallesi Camii”, Ondokuz Mayıs Üniversitesi İlahiyat Dergisi 40 (2016), 62.

${ }_{33}$ Muhammed Arslan, "Kars'ın Ahşap Destekli Köy Camileri”, Kafkas Üniversitesi Sosyal Bilimler Enstitüsü Dergisi 26 (2020), 586.

${ }^{34}$ Arslan, "Kars'ın Ahşap Destekli Köy Camileri”, 604.

${ }^{35}$ Necati Demir, "Trabzon ve Yöresinde Ahşap Camiler”, Gazi Üniversitesi Hacı Bektaş Veli Araştırma Dergisi 29 (2004), 169.

${ }^{36}$ Karpuz, "Trabzon'un Çaykara İlçesi Köylerinde Bulunan Bazı Camiler”, 285.

${ }^{37}$ Tuluk - Durmuş, “Araklı'nın Çok Kubbeli Camileri”, 112.

38 Sümerkan - Okman, Kültür Varlıklarıyla Trabzon-Cilt.1 İlçeler ve Köyler, 38.

${ }^{39}$ Karpuz, Trabzon Merkez ve İlçelerindeki Önemli Tarihi Yapılar, 59.

${ }^{40}$ Karpuz, Trabzon, 36.

${ }^{41}$ Hamit Şafakçı, "Osmanlı Dönemi Artvin-Merkez Camileri”, Karadeniz Sosyal Bilimler Dergisi 
Orta Camii $(1737)^{42}$, Giresun Hac1 Hüseyin Camii (1594) ${ }^{43}$, Gümüşhane Süleymaniye Mahallesi Ulu Camii (XVI) ${ }^{44}$, Seydibaba Köyü Camii (1797-98) ${ }^{45}$, Bayburt Dağçatı Köyü Camii $(1806)^{46}$ ve Çorum Abdülbaki Paşa Camii'ni $(1703)^{47}$ örnek verebiliriz.

Bölgedeki camilerin örtü sistemi dört omuz kırma çatıdır. Yağışlı iklim sebebiyle çatı saçakları genellikle geniş tutulmuştur. Ahşap veya taş-ahşap (karma) malzemeyle inşa edilen yapılarda bu genişlik 1.5-2 m arasında, yalnızca taş malzemeyle inşa edilen yapılarda ise 20 ila $70 \mathrm{~cm}$ arasında değişkenlik göstermektedir. Taş malzemeyle inşa edilen Güneyce Mahallesi Orta Camii ve Elmaalan Mahallesi Merkez Camii'nin saçak genişliği yaklaşık 40-50 cm civarındadır.

İncelemiş olduğumuz yapilarda çift sıra pencere düzeni mevcuttur. Güneyce Mahallesi Orta Camii'nin pencereleri dikdörtgen formlu ve basık kemerli, Elmaalan Mahallesi Merkez Camii'nin pencereleri ise dikdörtgen formlu ve yuvarlak kemerlidir. Akçaabat Dürbinar Mahallesi Camii (1746), Işıklar Mahallesi Orta Camii (1785), Orta Mahalle Merkez Camii (1800), Araklı Kayacık Mahallesi Camiin (1747), Araklı Hacı Hasan Camii (1859), Arsin Yeşilce Mahallesi Konak Camii (1822), Yolüstü Mahallesi Merkez Camii (1864), Güneyce Mahallesi Büyük Camii (1882-83), Atayurt Mahallesi Merkez Camii (1899), Işıklı Mahallesi Merkez Camii (1902), Gölgelik Mahallesi Camii (1904), Dernekpazarı Ormancık Mahallesi Merkez Camii (1892) ${ }^{48}$, Of Yazlık Mahallesi Merkez Camii (1951), Kireçli Mahallesi Camii (1952), Ortahisar (Merkez) Ebu Bekir (Semerciler) Camii (1759), Hızırbey Camii (1798), Sürmene Aşağı Ovalı Mahallesi Camii (1845), Yeniay Kuleli Mahallesi Camii (1893), Orta Mahalle Yalı Camii (1900), Tonya Sayraç Mahallesi Camii (1909) ve Yomra Sancak Mahallesi Kohalı Camii'nin (20.yy. başı) pencere formu, Güneyce Mahallesi Orta Camii pencereleriyle, Araklı Taşgeçit Mahallesi Camii (1950), Yalıboyu Mahallesi Merkez Camii (1954), Arsin Karaca Mahallesi Camii (1955), Cudibey Mahallesi Orta Camii (1955), Çiçekli Mahallesi Merkez Camii (1956), Beşikdüzü Seyitahmet Mahallesi Camii (1835-36), Korkuthan Mahallesi Camii (1894), Çaykara Taşkıran Mahallesi Camii (1896-97), Dernekpazarı Akköse Mahallesi Merkez Camii

8/15 (2016), 281.

${ }^{42}$ Ergün Lafl, "Rize'deki Osmanlı Dönemi Camileri”, Güncel Sanat 27 (2016), 23.

${ }^{43}$ Mustafa Şahin, “Giresun İlindeki Bağdadi Kubbeli Camiler”, TÜBA-KED Türkiye Bilimler Akademisi Kültür Envanteri Dergisi 11 (2013), 77.

${ }^{44}$ Haldun Özkan, “Gümüşhane'de Ahşap Tavanlı Camiler”, Sanat Dergisi 18 (2010), 75.

45 Özkan, "Gümüşhane'de Ahșap Tavanlı Camiler”, 76.

${ }^{46}$ Haldun Özkan, "Bayburt Dağçatı Köyü Camii ve Çeşmesi”, Atatürk Üniversitesi Güzel Sanatlar Enstitüsü Dergisi 31 (2014), 130.

${ }^{47}$ Abdülkadir Dündar, Çorum Cami ve Mescitleri (Ankara: Motif Yayınları, 2009), 199.

48 Yavuz, Çaykara ve Dernekpazarı'nda Geleneksel Köy Camileri, 107. 
(1865), Ortahisar (Merkez) Hatuncuk Hatun Camii (1523), Konak Camii $(18 . y y)^{49}$, Hacı Salih Camii (1807), Sürmene Çamlıca Camii (1827), Dirlik Mahallesi Camii (1890), Gültepe Mahallesi Kefeli Camii (1898) ve Karacakaya Mahallesi Camii (1901) pencereleri ise Elmaalan Mahallesi Merkez Camii'nin pencereleriyle benzerdir.

Çalışmamızın konusunu oluşturan camiler, taş malzemeli mihraba sahiptir. Ahşap yığma (çatı) tekniğinde inşa edilen camiler dışında Trabzon ilindeki tüm camilerde taş mihrap bulunur. Elmaalan Mahallesi Merkez Camii'nin mihrabı, barok-rokoko üslubunun etkilerini taşır. Söz konusu mihrabın benzeri Arsin Yeşilce Mahallesi Konak Camii (1822) ve Cudibey Mahallesi Orta Camii'nde (1955) görülür. Bu mihraplar muhtemelen aynı usta tarafında yapılmıştır. Genelde ahşap malzemeli mimari elemanlarda görmeye alışık olduğumuz motiflerle bezeli Güneyce Mahallesi Orta Camii mihrabı ise ünik bir örnektir.

Elmaalan Mahallesi Merkez Camii'nin minber ve vaaz kürsüsü orijinal olmayıp yakın dönemde eklenmiştir. Güneyce Mahallesi Orta Camii'nin orijinal minber ve vaaz kürsüsü ise sahip olduğu süslemeleriyle ahşap sanatının nadide örnekleri arasında yer alır. Geleneksel bezeme türleri arasında bulunan Türk ahşap sanatının 18. yüzyıl sonlarından itibaren Doğu Karadeniz bölgesine özgün bir gelişme gösterdiği ve belli bir kaliteye ulaştığ1 söylenebilir ${ }^{50}$. Söz konusu minber ve vaaz kürsüsü de bu kalitenin yansımasıdır.

Trabzon'un merkez ve ilçelerindeki cami minberlerinin neredeyse tümü klasik tiptedir. Ancak Arsin ilçesindeki camilerde, Güneyce Mahallesi Orta Camii'nde olduğu gibi köprü gibi alttan geçitli forma sahip minberler oldukça yaygındır. Bu tarz minber örnekleri Arsin dışında Araklı, Beşikdüzü, Dernekpazarı, Sürmene ve Vakfikebir ilçelerindeki bazı camilerde de görmek mümkündür. Arsin Güneyce Mahallesi Büyük Camii (1882-83), Işıklı Mahallesi Merkez Camii (1902), Güneyce Mahallesi Mandıra Camii (1925), Araklı Hacı Hasan Camii (1859), Taşgeçit Mahallesi Camii (1950), Yalıboyu Mahallesi Merkez Camii (1954), Ortaköy Mahallesi Merkez Camii (1957), Beşikdüzü Duygulu Mahallesi Merkez Camii (1846), Oğuz Mahallesi Merkez Camii (1912), Dernekpazarı Akköse Mahallesi Merkez Camii $(1865)^{51}$, Sürmene Aşağı Ovalı Mahallesi Camii $(1845)^{52}$ ve Vakfikebir Merkez Eski Camii (1794) köprü gibi alttan geçitli minbere sahip camilerden bazılarıdır.

\footnotetext{
${ }^{49}$ Kahrıman, Trabzon'daki Türk Devri Mimari Eserleri, 127.

50 Yavuz, "Doğu Karadeniz Köy Camilerinde Bezeme Anlayışı”, 313.

51 Taşkan, Trabzon İli Camilerinde Ahșap Minberler, 225.

52 Taşkan, Trabzon İli Camilerinde Ahşap Minberler, 519.
} 
Bölgedeki camilerin vaaz kürsüsü genellikle sandık tipli, yarım koni veya çeyrek koni formludur. Güneyce Mahallesi Orta Camii'nin kürsüsü de çeyrek koni formlu kürsüler grubuna girmektedir. Benzer kürsü örneklerini biz Arsin Güneyce Mahallesi Büyük Camii (1882-83), Atayurt Mahallesi Merkez Camii (1899), Akçaabat Nefsipulathane Mahallesi Camii (1750), Araklı Merkez Yeşilköy Fatih Sultan Mehmet Camii (1950-51), Çaykara Akdoğan Mahallesi Merkez Camii (1825 öncesi), Of Cumapazarı Serindere Mahallesi Camii (1884), Sürmene Gültepe Mahallesi Camii (1900) ve Tonya Kayacan Mahallesi Camii'nde (1892) de görürüz.

Trabzon camilerinde dikdörtgen, “U”, "L” ve üç yerden dalgalı olmak üzere dört farklı mahfil formu mevcuttur. Orijinal olan Güneyce Mahallesi Orta Camii mahfili dikdörtgen formluyken, orijinal olmayan Elmaalan Mahallesi Merkez Camii'nin mahfili üç yerden dalgalıdır. Dikdörtgen formlu mahfile sahip camilere Arsin Cudibey Mahallesi Orta Camii (1955), Akçaabat Dürbinar Mahallesi Camii (1746), Beşikdüzü Seyitahmet Mahallesi Camii (1835-36), Çaykara Kabataş Mahallesi Merkez Camii (1811) ${ }^{53}$, Köprübaşı Beşköy Mahallesi Yılmazlar Camii (1950), Maçka Kaynarca Mahallesi Camii (1950), Ortahisar (Merkez) Erdoğdu Bey Camii (1577), Ebu Bekir (Semerciler) Camii (1759), Hoca Halil Camii (1896), Şalpazarı Sütpınarı Mahallesi Merkez Camii (1908-09), Tonya Karşular Mahallesi Camii (1886), Yomra Sancak Mahallesi Kohalı Camii (20.yy. başı) ve Kaşüstü Merkez Camii'ni (1908), üç yerden dalgalı mahfile sahip camilere ise Arsin Yeşilce Mahallesi Konak Camii (1822), Işıklı Mahallesi Yeni Camii (1956), Akçaabat Orta Mahalle Merkez Camii (1800), Araklı Merkez Büyük Camii (1902), Kalecik Mahallesi Camii (1910), Çaykara Şahinkaya Mahallesi Gülveren Camii (1876-1887) ${ }^{54}$, Of Gürpınar Mahallesi Hacı Bayram Camii (1885), Sürmene Gültepe Mahallesi 2. Abdülhamit Camii (1867) ${ }^{55}$, Tonya İskenderli Merkez Camii (1810) ve Vakfikebir Merkez Eski Camii'ni (1794) örnek verebiliriz.

Türk İslam mimarisinde kubbe önemli bir yere sahip olsa da Trabzon'un kırsal bölgelerinde inşa edilen yapılar dıștan dört omuz kırma çatı ile örtülüdür. Kubbe inşa etmek maliyetli ve zaman isteyen bir iş olmasının yanında ustalık gerektiren bir iștir. Bu sebeple mahalle halkı tarafından, kısıtlı imkânlarla inşa ettirilen camilerde Güneyce Mahallesi Orta Camii ve Elmaalan Mahallesi Merkez Camii'nde olduğu gibi dört omuz kırma çatı tercih edilmiştir.

Camilerin harim bölümü istisnai örnekleri olmakla birlikte ya düz

\footnotetext{
53 İnce, "Kabataș Köyü Merkez Camii”, 228.

54 Yavuz, Çaykara ve Dernekpazari'nda Geleneksel Köy Camileri, 42.

55 Yavuz, "Sürmene-Gültepe Köyü Yukarı Kefeli Mahallesi Camii ve Şadırvanı", 511.
} 
ahşap tavanla ya da kolay ve az maliyetle yapılan bağdadi kubbeyle örtülüdür. İncelemiş olduğumuz Güneyce Mahallesi Orta Camii'nin harimi düz ahşap tavanla, Elmaalan Mahallesi Merkez Camii'nin harimi ise bağdadi kubbeyle örtülüdür. Düz ahşap tavana sahip camilerde genellikle kubbeyi simgeleyen tavan göbeği bulunmaktadır. Güneyce Mahallesi Orta Camii'nin harim duvarları ve tavanı yakın dönemde niteliksiz plastik lambri ile kaplandığı için tavan göbeği olup olmadığını bilemiyoruz. Ancak yakın bölgelerdeki benzer camilerden hareketle tavan göbeğinin olduğu muhtemeldir. Düz ahşap tavanlı olup tavan göbeğine sahip camilere Arsin Atayurt Mahallesi Lağdas Camii (1691), Güneyce Mahallesi Büyük Camii (1882-83), Atayurt Mahallesi Merkez Camii (1899) ${ }^{56}$, Güneyce Mahallesi Mandıra Camii (1925), Akçaabat Işıklar Mahallesi Orta Camii (1785), Araklı Turnalı (Os) Mahallesi Camii (1841-42) ${ }^{57}$, Çaykara Uzuntarla Mahallesi Karaçam Camii (1802), Uzungöl Mahallesi Filak Camii (1812-13) $)^{58}$, Dernekpazarı Kondu Mahallesi Merkez Camii (1780'ler), Taşçılar Mahallesi Merkez Camii (1804-05) ${ }^{59}$, Akköse Mahallesi Merkez Camii $(1865)^{60}$, Hayrat Dereyurt Merkez Eski Camii (1832) ${ }^{61}$, Sarmaşık Mahallesi Camii (1877), Köprübaşı Arpalı Mahallesi Camii (1890), Beşköy Mahallesi Yılmazlar Camii (1950), Maçka Ormaniçi Mahallesi Camii (1852), Esiroğlu Mahallesi Işıklar Camii (1873) ${ }^{62}$, of Hüseyin Hoca Köyü Sahil Camii (1834), Sugeldi Mahallesi Aşağ Camii (1834-35) ${ }^{63}$, Ortahisar (Merkez) Hatuncuk Hatun Camii (1523), Erdoğdu Bey Camii (1577), Sürmene Aşağ1 Ovalı Mahallesi Camii (1845), Çamburnu Kuşluca Camii (1893), Şalpazarı Doğancı Mahallesi Merkez Camii (1871-72), Tonya Bicinlik Mahallesi Camii (1898) ve Vakfikebir Ortaköy Mahallesi Camii’ni (1876) örnek verebiliriz. Arsin Yeşilce Mahallesi Konak Camii (1822), Işıklı Mahallesi Merkez Camii (1902) ${ }^{64}$, Çubuklu Mahallesi Merkez Camii (1954), Cudibey Mahallesi Orta Camii (1955), Çiçekli Mahallesi Merkez Camii (1956), Akçaabat Derecik Mahallesi Demirtaş Derecik-Karaman Merkez Camii (20. yy), Be-

\footnotetext{
${ }^{56}$ Kazaz, Trabzon Kirsal Cami Mimarisi, 369.

57 Yavuz, "Oslu Müderris Hacı Hasan Efendi ve Onun Manevi Etki Alanında Oluşan Mimari Yap1laşma”, 269-270.

58 Aydın - Perker, “Trabzon Uzungöl Filak Ahşap Cami Yapısal Özellikleri”, 1267.

59 Zorlu, "Doğu Karadeniz Ahşap Camilerinde Restorasyon: Dernekpazarı Taşçılar Köyü Camii ve Medresesi Örneği”, 188.

${ }^{60}$ Karpuz, "Doğu Karadeniz Bölgesinde Bazı Ahşap Camiler”, 43.

${ }^{61}$ Enbiya Yıldırım, "Dereyurt Köyü Tarihi Camii”, I. Uluslararası Geçmişten Günümüze Trabzon'da Dini Hayat Sempozyumu, ed. Şenol Saylan - Betül Saylan (İstanbul: Değişim Yayınları, 2016), 2/1119.

${ }^{62}$ Tuluk - Kazaz, “Trabzon Değirmendere Vadisi’nde Geç Dönem Osmanlı Mirası: Kırsal Cami Geleneği Üzerine Bir Tipoloji Denemesi”, 140.

${ }^{63}$ Sarı, Trabzon'un Hayrat, Of ve Sürmene İlçelerindeki Köy Camileri, 116.

${ }^{64}$ Şahin, Giresun ve Trabzon İllerindeki Bağdadi Kubbeli Camiler, 108.
} 
şikdüzü Dolanlı Mahallesi Merkez Camii (1869) ${ }^{65}$, Oğuz Mahallesi Merkez Camii (1912), Çaykara Şahinkaya Mahallesi Gülveren Camii (1876-1887) ${ }^{66}$, Hayrat Kurtuluş Mahallesi Camii (1919), Maçka Esiroğlu Mahallesi Durali Camii (1949), Kaynarca Mahallesi Camii (1950), of Ağaçseven Mahallesi Merkez Camii (1820) ${ }^{67}$, Sürmene Orta Mahalle Yalı Camii (1900), Rize Orta Camii (1737) ${ }^{68}$, Artvin Borçka Muratlı (Maradit) Köyü Camii (1845-46) ${ }^{69}$, Giresun Bulancak Eski (Çarşı) Camii (1847) ${ }^{70}$, Hacı Hüseyin Camii (1861) ${ }^{71}$ ve Gürcistan-Acara Keda Zunduga Camii (18. yy. son çeyrek) ${ }^{72}$ ise Elmaalan Mahallesi Merkez Camii gibi bağdadi kubbelidir.

Trabzon cami mimarisi iklim, coğrafya, sosyal yapı ve ekonomik etkenlerle şekillenmiştir. Camiler, kuzey-güney doğrultuda uzayan basit dikdörtgen planlı olup dört omuz kırma çatılıdır. Genellikle taş malzemeyle yı̆̆ma taş tekniğinde inşa edilen camilerin mimari ve yapı elemanları ahşaptır. Dışarıdan bakıldı̆̆ı sade görünen yapıların harim kısmı oldukça süslüdür. Süsleme programını oluşturan motifler, klasik Osmanlı, barok, rokoko ve Kafkasya kökenlidir ${ }^{73}$. Söz konusu motifler, yöresel sanatçılar tarafından sentezlenerek bölgeye özgü bezeme anlayışı ortaya çıkarılmıştır. 1960’lı yıllara kadar geleneksel olarak inşa edilen camiler, ekonomik ve ulaşım gibi şartların gelişmesiyle yerini yavaş yavaş betonarme malzemeli ve kubbeli camilere bırakmıştır. Katalog yöntemiyle ayrıntılı olarak tanıttığımız Güneyce Mahallesi Orta Camii ve Elmaalan Mahallesi Merkez Camii, betonarme malzemeli ve kubbeli yapıların mimari hayatımıza girdiği dönemde geleneksel yöntemlerle inşa edilmiş yapılardır. Kuzeygüney doğrultuda uzayan basit dikdörtgen planları, dört omuz kırma çatılı örtü sistemleri, taş malzemeyle yı̆̆ma taş tekniğinde yapılmış cephe duvarları ve süslemeleri bunun en güzel göstergesidir. Yüzyıllardır süre gelen bir geleneğin ürünleri olduğunu düşündüğümüz bu camilerin gelecek nesillere aktarılması elzemdir. Bu yüzden Elmaalan Mahallesi Merkez Camii de Güneyce Mahallesi Orta Camii gibi ilgili kurum tarafından tescil edilmelidir. Ayrıca söz konusu yapılar niteliksiz müdahalelerden arındı-

${ }^{65}$ Şahin, Giresun ve Trabzon İllerindeki Bağdadi Kubbeli Camiler, 122.

${ }^{66}$ Tuluk - Kazaz, “Trabzon Bölgesindeki Kırsal Cami Mimarisi Üzerine Tipolojik Bir Değerlendirme", 1143.

67 Şahin, Giresun ve Trabzon illerindeki Bağdadi Kubbeli Camiler, 181.

${ }_{68}$ Laflı, "Rize'deki Osmanlı Dönemi Camileri", 23.

${ }^{69}$ Taşkan, Artvin İli Borçka ve Hopa İlçeleri Camilerinde Ahşap Süslemeler, 144.

70 Şahin, "Giresun İlindeki Bağdadi Kubbeli Camiler", 77.

71 Şahin, "Giresun İlindeki Bağdadi Kubbeli Camiler", 78.

${ }^{72}$ Selçuk Seçkin, “Gürcistan/Acara Keda Bölgesi'ndeki Osmanlı Dönemi Camileri”, Turkish Studies 13/18 (2018), 1145.

73 Özen, Hamiyet - Aksakal, Hamiyet. "Trabzon Kenti Kırsal Camilerinde Süsleme Programlarının İncelenmesi “http://www.academia.edu/2496388."Traditional_Rural_Mosques_of_Eastren_Black_Sea_Region”. Erişim 22.05.2021. 
rilıp özgün haline getirilmelidir. Aksi halde birçok cami gibi ya yok olup gideceklerdir, ya da özgünlüklerini tamamen kaybedeceklerdir.

\section{Kaynakça}

Akçll Harmankaya, N. Çiçek. "Kastamonu Talipler Köyü Rüstem Paşa Camii”. History Studies 11/4 (2019), 1243-1263.

Arslan, Muhammed. "Kars'in Ahşap Destekli Köy Camileri”. Kafkas Üniversitesi Sosyal Bilimler Enstitüsü Dergisi 26 (2020), 577-614.

Aydın, Hasan - Perker, Sevgen. “Trabzon Uzungöl Filak Ahşap Cami Yapısal Özellikleri”. Elektronik Sosyal Bilimler Dergisi 16/63 (2017), 1262-1269.

Aydın, Hasan - Perker, Sevgen. “Trabzon'dan Ahşap Bir Cami Örneği: Of-Bölümlü Mithat Paşa Camii". Journal of History Culture and Art Research 6/2 (2017), 457472.

Aygün, Necmettin. Of Kazasi'nda Dini Yapilar ve Görevlileri (1691-1833) -(Of'un İskân Tarihine Hurufat Kayttlarinin Katkısı). Ankara: Serander Yayınları, 2021.

Aytekin, Osman. "Serhat Boylarında Bir Osmanlı Dönemi Yapısı Muratlı Merkez Camii”. Güzel Sanatlar Enstitüsü Dergisi 4 (1998), 37-47.

Coşkun, Rümeysa - Çelebioğlu, Banu. "Artvin Borçka'daki Yığma Ahşap Camiler". bâb Mimarlk ve Tasarım Dergisi 1/2 (2020), 142-160.

Çalık, İsmet - vd.. "Doğu Karadeniz Bölgesi Tarihi Yığma Camilerinin Restorasyonlarının Yapısal Değerlendirilmeleri”. 5. Tarihi Eserlerin Güçlendirilmesi ve Geleceğe Güvenle Devredilmesi Sempozyumu. 1/185-200. Erzurum: Zafer Medya Grup, 2015.

Demir, Necati. “Trabzon ve Yöresinde Ahşap Camiler”, Gazi Üniversitesi Hacı Bektaş Veli Araștırma Dergisi 29 (2004), 169-188.

Dündar, Abdülkadir. Çorum Cami ve Mescitleri. Ankara: Motif Yayınları, 2009.

İnce, Kasım. "Kabataş Köyü Merkez Camii/Çaykara/Trabzon". Vakıflar Dergisi 28 (2004), 226-236.

Kahrıman, Ömer. Trabzon'daki Türk Devri Mimari Eserleri. Erzurum: Atatürk Üniversitesi, Sosyal Bilimler Enstitüsü, Yüksek Lisans Tezi, 2003.

Karaçay, Çiğdem. "Çorum Üçköy Köyü Camii: Mimari ve Süsleme Özellikleri”. Hitit Üniversitesi Sosyal Bilimler Enstitüsü Dergisi 12/2 (2019), 521-538.

Karpuz, Haşim. "Doğu Karadeniz Bölgesinde Bazı Ahşap Camiler". Sanat Tarihi Araştırmaları Dergisi 4 (1989), 37-45.

Karpuz, Haşim. "Trabzon'un Çaykara İlçesi Köylerinde Bulunan Bazı Camiler". Vakıflar Dergisi 21 (1990), 281-299.

Karpuz, Haşim. Trabzon. Ankara: Kültür Bakanlığı Yayınları, 1990.

Karpuz, Haşim. Trabzon Merkez ve İlçelerindeki Önemli Tarihi Yapılar. Ankara: Türk Tarih Kurumu Yayınları, 2018.

Kazaz, Emriye. Trabzon Kirsal Cami Mimarisi. Trabzon: Karadeniz Teknik Üniversitesi, Fen Bilimleri Enstitüsü, Doktora Tezi, 2016. 
Koçyiğit, Fazilet. "Amasya'da Ahşap Tavanlı İki Cami Örneği: Şıhlar ve Kızılkışlacık Köyü Camileri”. MANAS Sosyal Araştırmalar Dergisi 8/2 (2019), 1641-1658.

Lafl, Ergün. “Rize'deki Osmanlı Dönemi Camileri”. Güncel Sanat 27 (2016), 21-27.

Nefes, Eyüp. “Giresun'da Yeni Tespit Edilen Bir ahşap Cami; Çaldağ Beldesi Melikli Mahallesi Tahtalı Camii”. Dinbilimleri Akademik Araştırma Dergisi 9/2 (2009), 187-210.

Nefes, Eyüp - Gün, Recep. “Çorum/İskilip’te Çantı Tekniğinde İnşa Edilmiş İki Cami: Sanayi Marangozlar ve Tavukçuhoca Camileri”. Hitit Üniversitesi İlahiyat Fakültesi Dergisi 15/30 (2016), 299-309.

Nefes, Eyüp - Gün, Recep. "Samsun/Kavak'ta Çantı Tekniğinde İnşa Edilen Alagömlek Köyü Rahmioğlu Mahallesi Camii”. Ondokuz Mayıs Üniversitesi İlahiyat Dergisi 40 (2016), 49-65.

Özen, Hamiyet - Aksakal, Hamiyet. “Trabzon Kenti Kirsal Camilerinde Süsleme Programlarının İncelenmesi "http://www.academia.edu/2496388. “Traditional_Rural_Mosques_of_Eastren_Black_Sea_Region”. Erişim 22.05.2021.

Özkan, Haldun. “Gümüşhane'de Ahşap Tavanlı Camiler”. Sanat Dergisi 18 (2010), 63-80.

Özkan, Haldun. “Bayburt Dağçatı Köyü Camii ve Çeşmesi”. Atatürk Üniversitesi Güzel Sanatlar Enstitüsü Dergisi 31 (2014), 119-135.

Özkurt, Muhammet. Rize Ahşap Camilerinde Süsleme. Karabük: Karabük Üniversitesi, Lisansüstü Eğitim Enstitüsü, Yüksek Lisans Tezi, 2020.

Sarı, Yavuz. Trabzon'un Hayrat, of ve Sürmene İlçelerindeki Köy Camileri. Samsun: Ondokuzmayıs Üniversitesi, Sosyal Bilimler Enstitüsü, Yüksek Lisans Tezi, 2016.

Sarı, Yavuz. Trabzon ve İlçelerinde Camiler. Samsun: Ondokuz Mayıs Üniversitesi, Lisansüstü Eğitim Enstitüsü, Doktora Tezi, 2021.

Seçkin, Selçuk. “Gürcistan/Acara Keda Bölgesi'ndeki Osmanlı Dönemi Camileri”. Turkish Studies 13/18 (2018), 1133-1169.

Sümerkan, M. Reşat - Okman, İbrahim. Kültür Varlıklarıyla Trabzon-Cilt.1 İlçeler ve Köyler. Trabzon: T.C. Trabzon Valiliği İl Kültür Müdürlüğü Yayınları, 1999.

Şafakçı, Hamit. “Osmanlı Dönemi Artvin-Merkez Camileri”. Karadeniz Sosyal Bilimler Dergisi 8/15 (2016), 261-282.

Şahin, Mustafa. Giresun ve Trabzon İllerindeki Bağdadi Kubbeli Camiler. Ankara: Gazi Üniversitesi, Sosyal Bilimler Enstitüsü, Yüksek Lisans Tezi, 2006.

Şahin, Mustafa. "Giresun İlindeki Bağdadi Kubbeli Camiler”. TÜBA-KED Türkiye Bilimler Akademisi Kültür Envanteri Dergisi 11 (2013), 71-89.

Taşkan, Demet. Artvin İli Borçka ve Hopa İlçeleri Camilerinde Ahşap Süslemeler, Ankara: Gazi Üniversitesi, Sosyal Bilimler Enstitüsü, Yüksek Lisans Tezi, 2011.

Taşkan, Demet. Trabzon İli Camilerinde Ahşap Minberler. Ankara: Gazi Üniversitesi, Sosyal Bilimler Enstitüsü, Doktora Tezi, 2016.

Tuluk, Ö. İskender - Kazaz, Emriye. “Trabzon Bölgesindeki Kırsal Cami Mimarisi Üzerine Tipolojik Bir Değerlendirme”. 1. Uluslararası Geçmişten Günümüze 
Trabzon'da Dini Hayat Sempozyumu. Ed. Şenol Saylan - Betül Saylan. 1/11291146. İstanbul: Değişim Yayınları, 2015.

Tuluk, Ö. İskender - Durmuş, Serap. “Araklı'nın Çok Kubbeli Camileri”. Tasarım Kültür Dergisi 208 (Aralık 2007), 110-116.

Tuluk, Ö. İskender - Kazaz, Emriye. “Trabzon Değirmendere Vadisi'nde Geç Dönem Osmanlı Mirası: Kırsal Cami Geleneği Üzerine Bir Tipoloji Denemesi”, Osmanlı'da Mimari, Sanat ve Yemek Kültürü, ed. M. Bedizel Zülfikar - Ravza Aydın. 1/133-147. İstanbul: Mahya Yayınları, 1. Basım, 2017.

Yavuz, Mehmet. Çaykara ve Dernekpazarı'nda Geleneksel Köy Camileri. Ankara: Türkiye Diyanet Vakfi Yayınları, 2009.

Yavuz, Mehmet. "Oslu Müderris Hacı Hasan Efendi ve Onun Manevi Etki Alanında Oluşan Mimari Yapılaşma”. Uluslararası Sosyal Araştırmalar Dergisi 2/7 (Bahar 2009), 263-305.

Yavuz, Mehmet. "Doğu Karadeniz Köy Camilerinde Bezeme Anlayışı”. Uluslararası Sosyal Araştırmalar Dergisi 2/6 (Kış 2009), 306-322.

Yavuz, Mehmet. "Sürmene-Gültepe Köyü Yukarı Kefeli Mahallesi Camii ve Şadırvanı” Uluslararası Sosyal Araştırmalar Dergisi 7/31 (2014), 498-515.

Yıldırım, Enbiya. “Dereyurt Köyü Tarihi Camii”. I. Uluslararası Geçmişten Günümüze Trabzon'da Dini Hayat Sempozyumu, ed. Şenol Saylan - Betül Saylan. 2/11151146. İstanbul: Değişim Yayınları, 2016.

Zorlu, Tülay. "Doğu Karadeniz Ahşap Camilerinde Restorasyon: Dernekpazarı Taşçılar Köyü Camii ve Medresesi Örneği”. Vakıflar Dergisi 32 (2009), 181-212. 


\section{Çizimler ve Fotoğraflar}

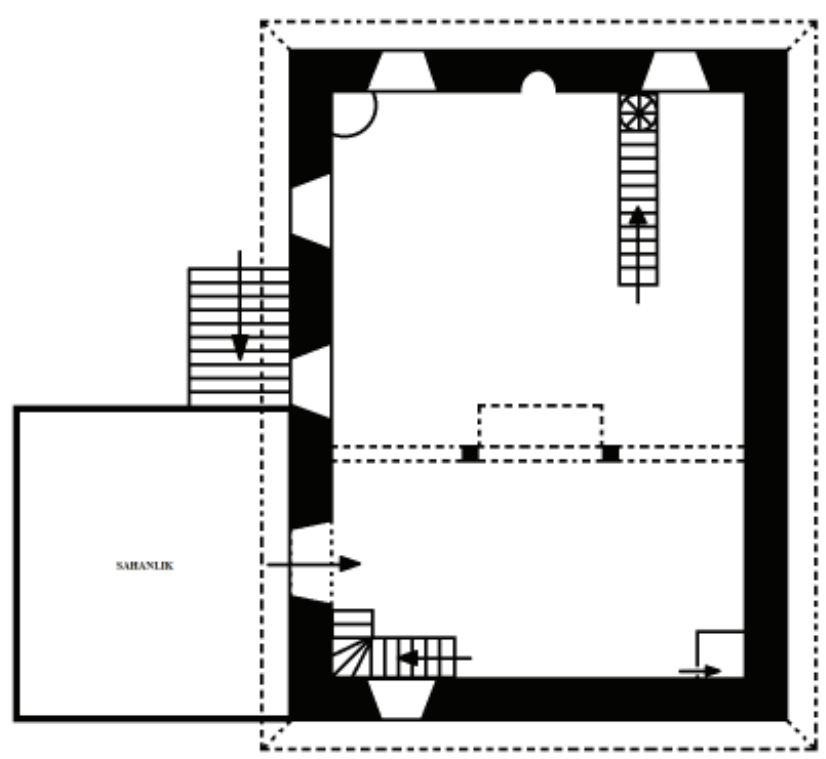

Çizim 1. Güneyce Mahallesi Orta Camii Plan

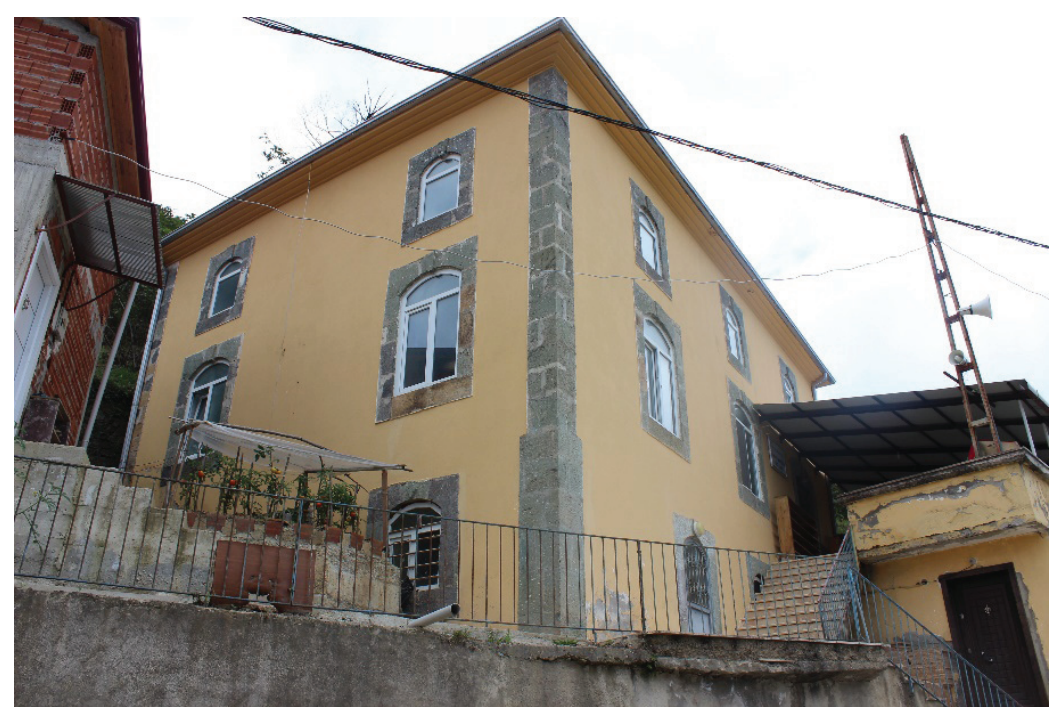

Fotoğraf 1. Güneyce Mahallesi Orta Camii Genel Görünüm 
402 Yavuz SARI

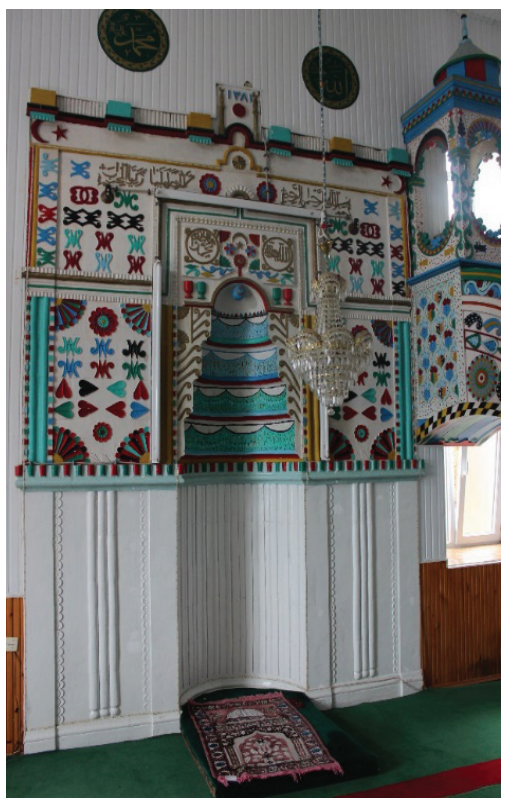

Fotoğraf 2. Güneyce Mahallesi Orta Camii Mihrap

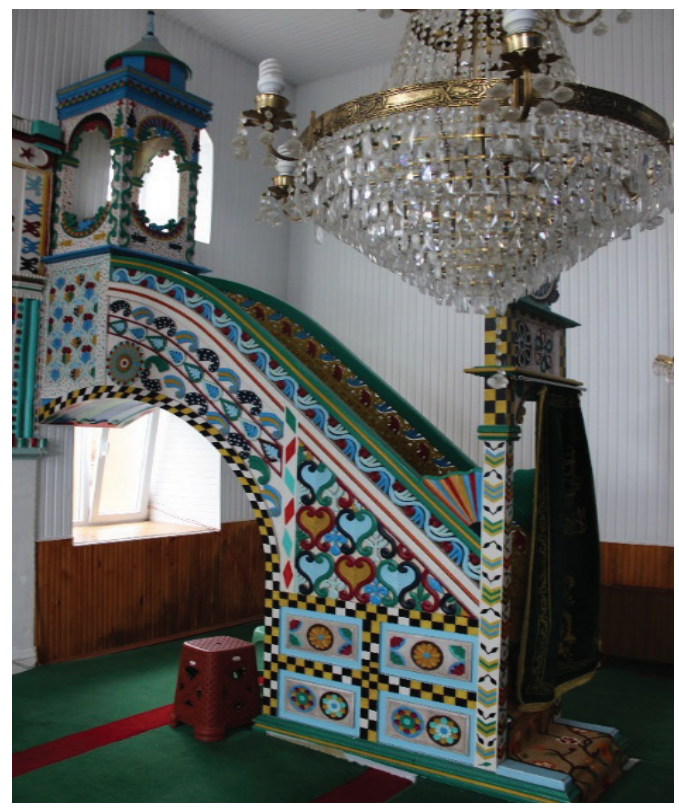

Fotoğraf 3. Güneyce Mahallesi Orta Camii Minber 


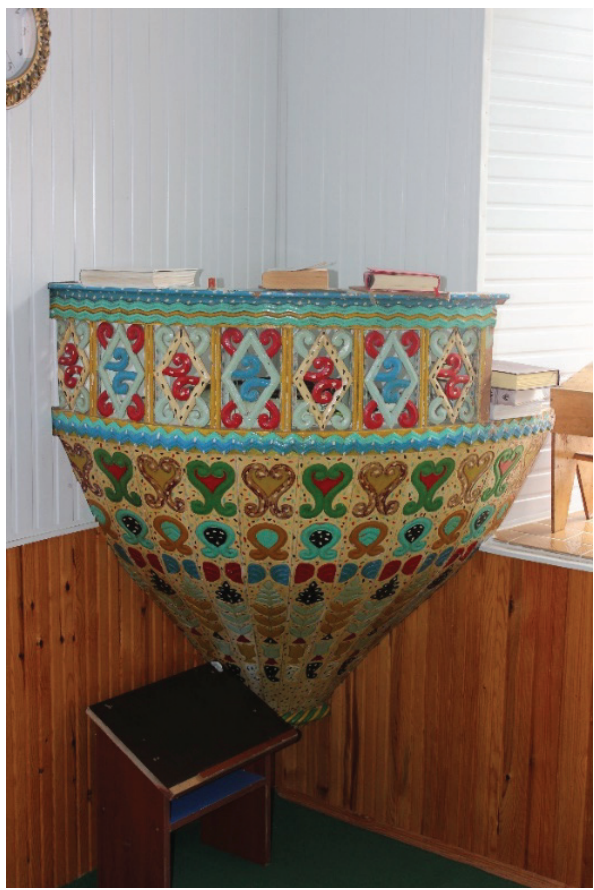

Fotoğraf 4. Güneyce Mahallesi Orta Camii Vaaz Kürsüsü

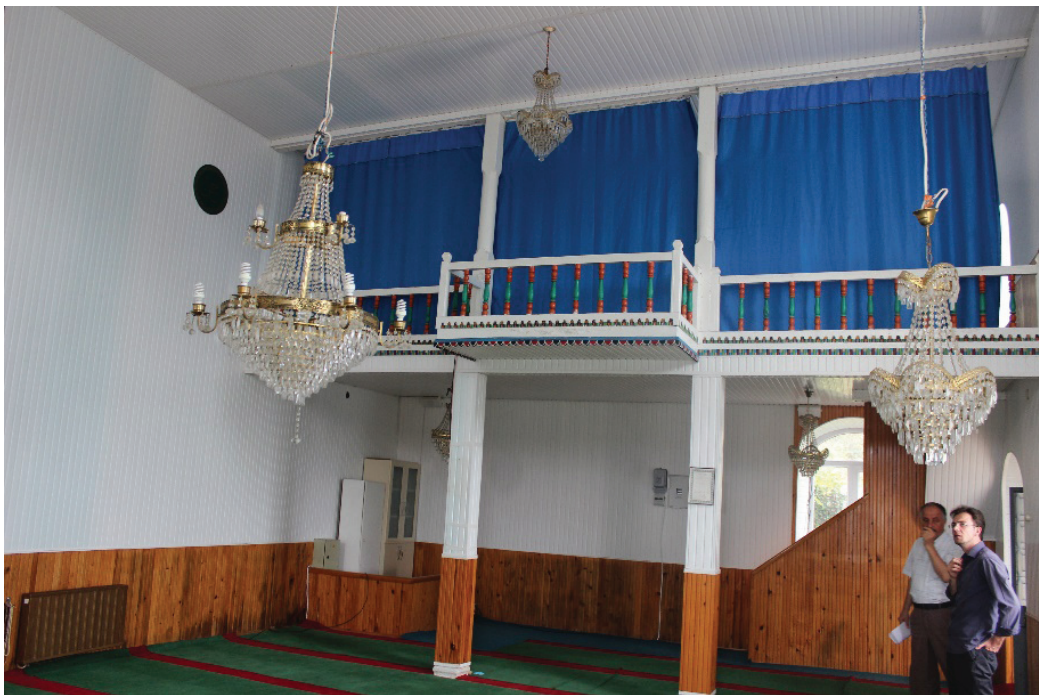

Fotoğraf 5. Güneyce Mahallesi Orta Camii Mahfil 


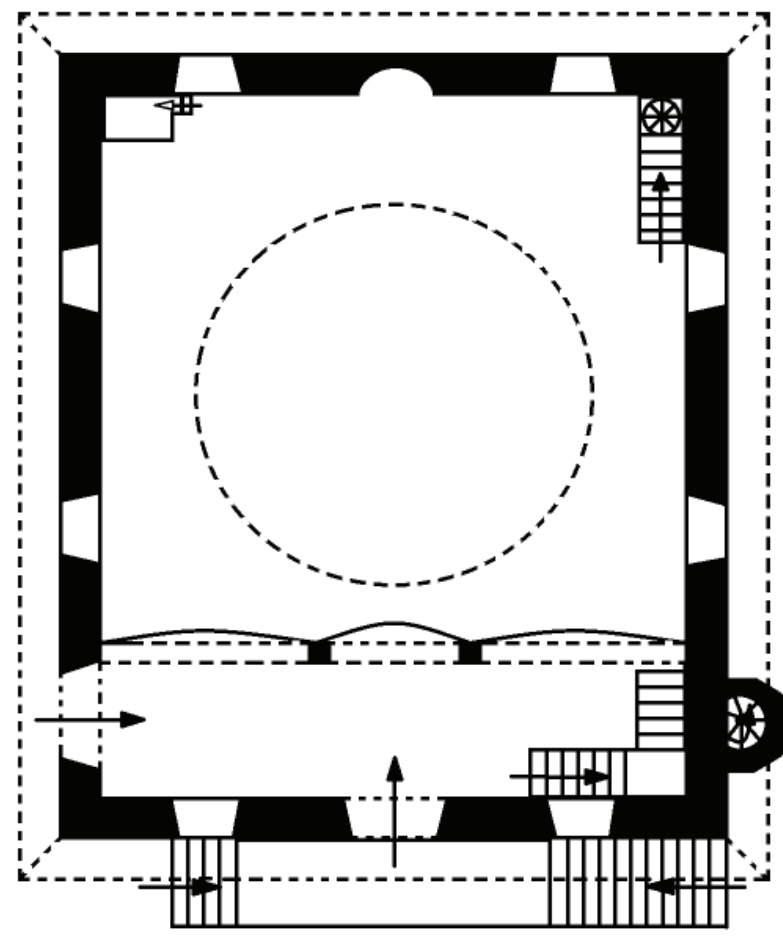

Çizim 2. Elmaalan Mahallesi Merkez Camii Plan

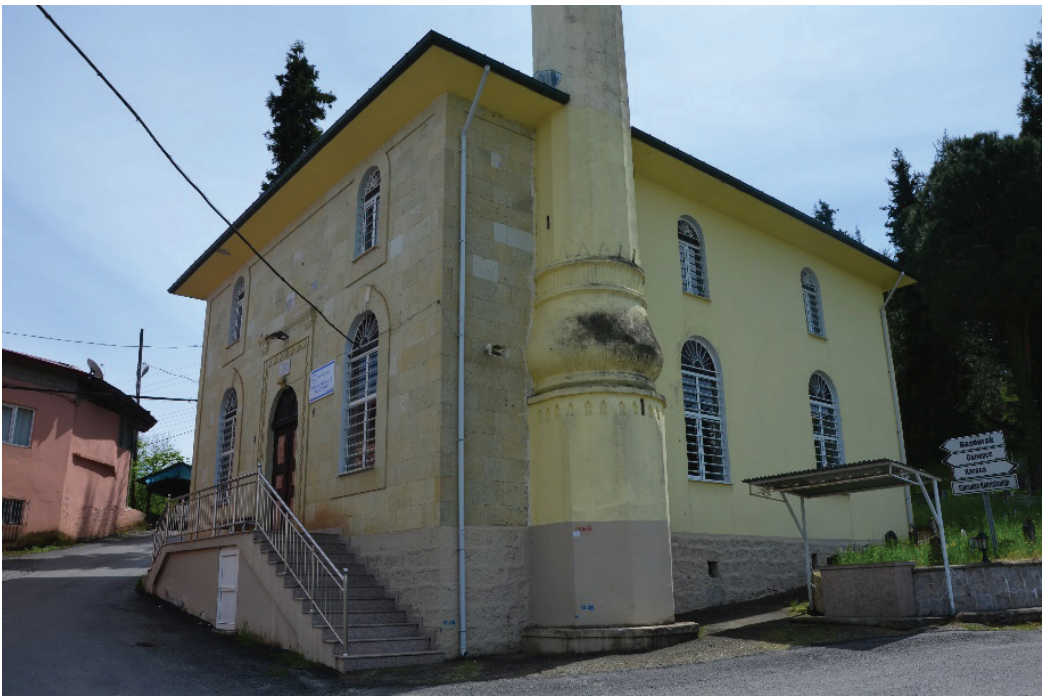

Fotoğraf 6. Elmaalan Mahallesi Merkez Camii Genel Görünüm 


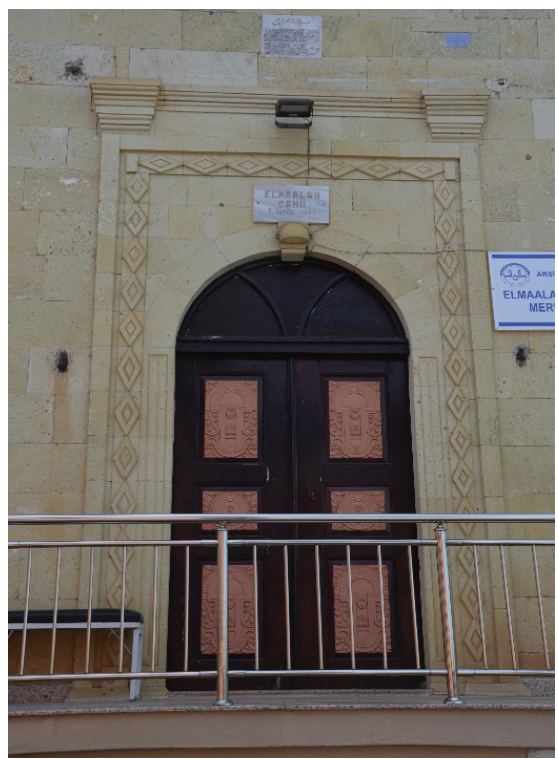

Fotoğraf 7. Elmaalan Mahallesi Merkez Camii Kuzey Cephe Ana Giriş Kapis1

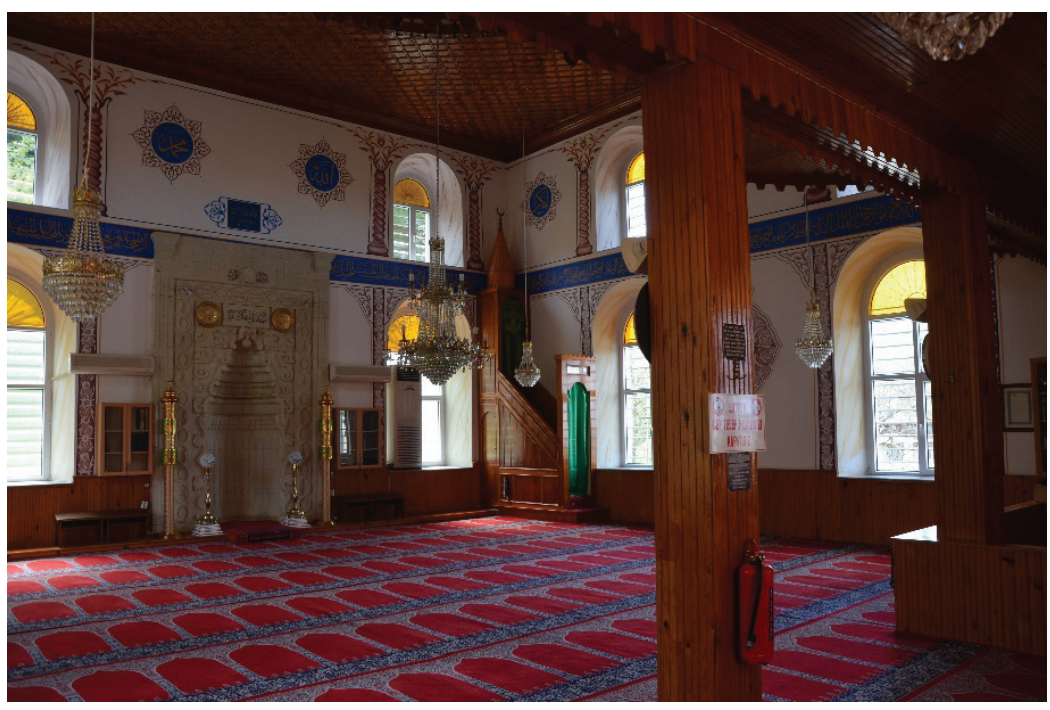

Fotoğraf 8. Elmaalan Mahallesi Merkez Camii Harim Genel Görünüm 
406 Yavuz SARI

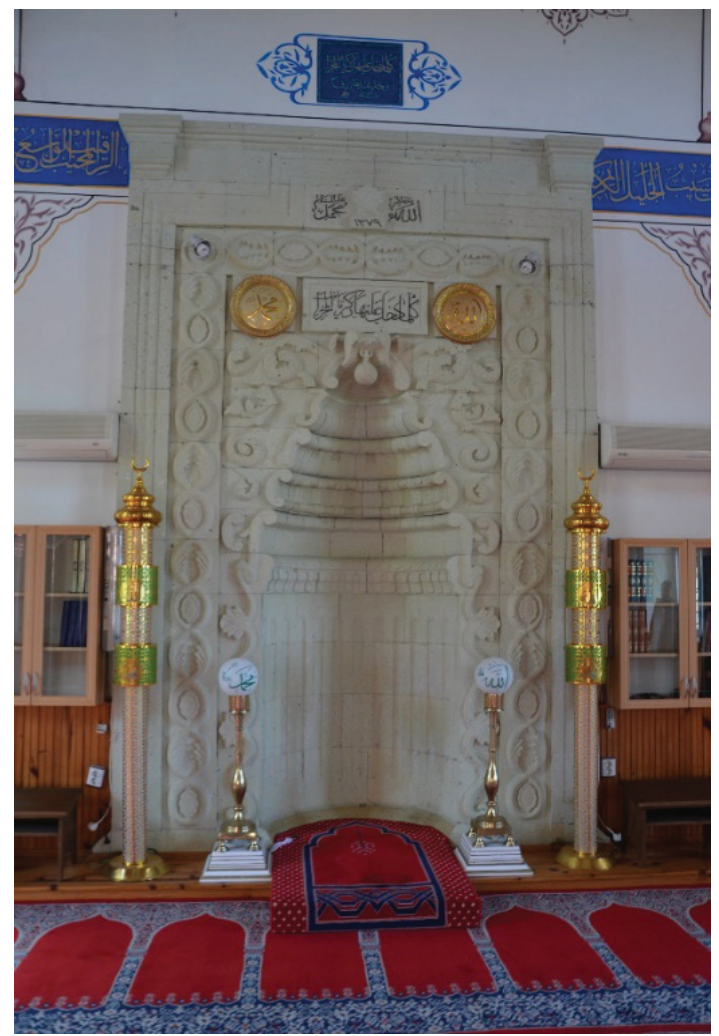

Fotoğraf 9. Elmaalan Mahallesi Merkez Camii Mihrap

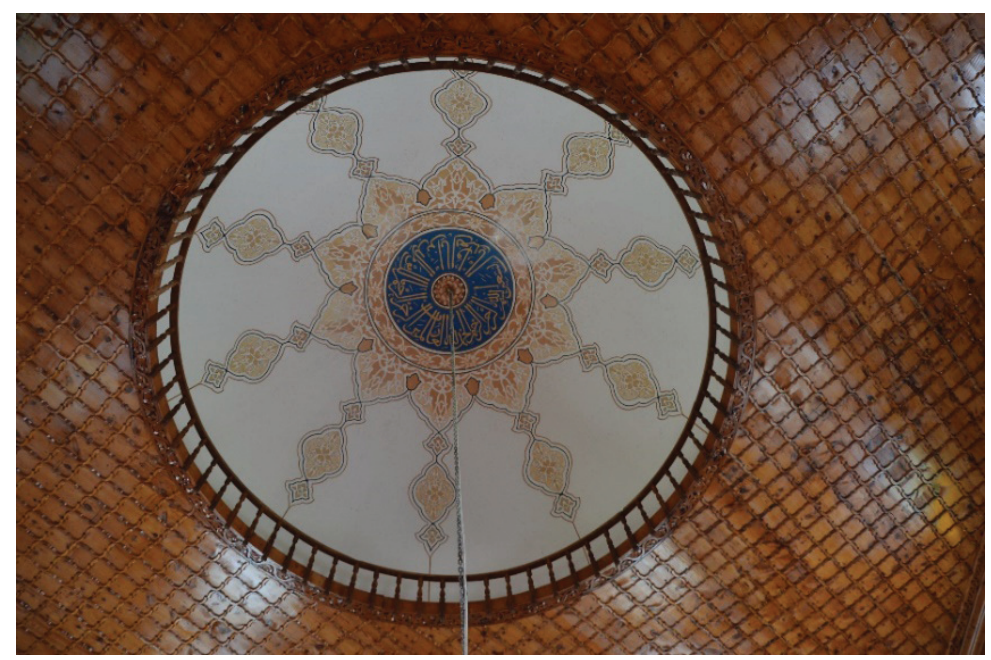

Fotoğraf 10. Elmaalan Mahallesi Merkez Camii Bağdadi Kubbe 